\title{
ECUT Energy Data Reference Series: High-Temperature Materials for Advanced Heat Engines
}
R. B. Abarcar
G. J. Hane
D. R. Johnson

July 1984

Prepared for the U.S. Department of Energy under Contract DE-AC06-76RLO 1830

Pacific Northwest Laboratory Operated for the U.S. Department of Energy by Battelle Memorial Institute 


\title{
DISCLAIMER
}

This report was prepared as an account of work sponsored by an agency of the United States Government. Neither the United States Government nor any agency thereof, nor any of their employees, makes any warranty, express or implied, or assumes any legal liability or responsibility for the accuracy, completeness, or usefulness of any information, apparatus, product, or process disclosed, or represents that its use would not infringe privately owned rights. Reference herein to any specific commercial product, process, or service by trade name, trademark, manufacturer, or otherwise, does not necessarily constitute or imply its endorsement, recommendation, or favoring by the United States Government or any agency thereof. The views and opinions of authors expressed herein do not necessarily state or reflect those of the United States Government or any agency thereof.

\author{
PACIFIC NORTHWEST LABORATORY \\ operated by \\ BATTELLE \\ for the \\ UNITED STATES DEPARTMENT OF ENERGY \\ under Contract DE-AC06-76RLO 1830
}

Printed in the United States of America

Available from

National Technical Information Service

United States Department of Commerce

5285 Port Royal Road

Springfield, Virginia 22161

NTIS Price Codes

Microfiche A01

$\begin{array}{cr}\text { Printed Copy } & \begin{array}{r}\text { Price } \\ \text { Codes }\end{array} \\ \text { Pages } & \text { A02 } \\ 001-025 & \mathrm{~A} 03 \\ 026-050 & \mathrm{~A} 04 \\ 051-075 & \mathrm{~A} 05 \\ 076-100 & \mathrm{~A} 06 \\ 101-125 & \mathrm{A07} \\ 126-150 & \mathrm{~A} 08 \\ 151-175 & \mathrm{~A} 09 \\ 176-200 & \mathrm{~A} 010 \\ 201-225 & \mathrm{~A} 011 \\ 226-250 & \mathrm{~A} 012 \\ 251-275 & \mathrm{~A} 013 \\ 276-300 & \end{array}$


ECUT ENERGY DATA REFERENCE SERIES: HIGH-TEMPERATURE MATER IALS FOR ADVANCED HEAT ENGINES
R. B. Abarcar(a)
G. J. Hane
D. R. Johnson

July 1984

Prepared for

Energy Conversion and Utilization Technologies Division

Office of Energy Systems Research Conservation and Renewable Energy U.S. Department of Energy under Contract DE-ACO6-76RLO 1830

Pacific Northwest Laboratory Richland, Washington 99352

(a) Energetics, Inc. Columbia, Maryland 


\section{ACKNOWLEDGMENTS}

This series was a substantial undertaking that even now would not be accomplished were it not for the significant efforts of Dan Johnson. Dan saw the need for the series and had the vision to patiently persevere through all the obstacles in data gathering, report writing, and finally publication. In the later stages of this work, Judy Danko provided critical editorial assistance and encouragement. It was through her efforts that all the volumes of this series were completed and published simultaneously.

D. L. Brenchley

Project Manager 


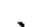

.

.

. 


\section{PREFACE}

This study was completed for the Division of Energy Conversion and Utilization Technologies (ECUT) in the Department of Energy. The division's mission has three parts:

1. to monitor advances in basic scientific research and evaluate them for their applicability to energy conservation

2. to perform exploratory development on novel or innovative conservation concepts

3. to expand the technology base for advanced conservation technologies. To aid in achieving this mission the ECUT staff established a planning and systems analysis function to identify and assess the array of opportunities for energy conservation R\&D.

This on-going activity provides ECUT Staff with the information necessary to decide where to invest limited research dollars to derive the maximum benefit to the public. As part of its systems analysis role for ECUT, PNL pUD1 ished a general energy use data book covering all major end-use sectors (Imhoff, Liberman, and Ashton 1982). In contrast, the current ECUT Energy Data Reference Series is more narrowiy targeted; each volume contains detailed capital stock and energy-use data for selected end-use sectors that are likely to be most impacted by existing or proposed ECUT R\&D activities.

This volume relates to the ECUT R\&D activity in high-temperature materials. The overall objective of this work element is to explore innovative concepts in high-temperature materials for applications in, among other things, advanced heat engines. The work specifically evaluates the potential of materials such as long-range ordered alloys and aluminides, and the development of technologies for joining ceramics used in advanced heat engines. In terms of impact and end-use market sectors, heat engines are only the intermediate application. This volume addresses the application of advanced heat engines in the transportation sector.

Other volumes in the ECUT Energy Data Reference Series include: 
Hane, G. J. and D. R. Johnson. 1984 ECUT Energy Data Reference Series: Otto Cycle Engines in Transportation. PNL-5191, Pacific Northwest Laboratory, Richland, Washington.

Abarcar, R. B., G. J. Hane and D. R. Johnson. 1984. ECUT Energy Data Reference Series: Lightweight Materials for Ground Transportation. PNL-5192, Pacific Northwest Laboratory, Richland, Washington.

Young, J. K. and D. R. Johnson. 1984. ECUT Energy Data Reference Series: Ammonia Synthesis Energy-Use and Capital Stock Information. PNL-5194, Pacific Northwest Laboratory, Richland, Washington.

Chockie, A. D. and D. R. Johnson. 1984. ECUT Energy Data Reference Series: Boilers. PNL-5195, Pacific Northwest Laboratory, Richland, Washington.

The bulk of the research for this series was conducted in calendar year 1982. While the data portrayed in these publications have not changed dramatically, certain trends, particularly those that were forecast, may have shifted in the interim between research and publication.

The ECUT Data Reference Series is part of a series of studies in support of the ECUT research planning effort. Other ECUT publications are:

Bomelburg, H. J. 1983. Efficiency Evaluation of Oxygen Enrichment in Energy Conversion Processes. PNL-4917, Pacific Northwest Laboratory, Richland, Washington.

Chockie, A., et al. 1983. "An Overview of Research Requirements for Stationary Combustion Systems." In Proceedings of the 18th Intersociety Energy Conversion Engineering Conference, pp. 2092-2098. Ámerican Institute of Chemical Engineers, 345 E. 47 St., New York, New York.

Hane, G. 1983. Efficiency Evaluation of the DISC, DHC, and DI Diesel Engines. PNL-4568, Pacific Northwest Laboratory, Richland, Washington.

Hane, G., et a1. 1983. A Preliminary Overview of Innovative Industrial Materials Processes. PNL-4505, Pacific Northwest Laboratory, Richland, Washington.

Hane, G., et al. 1984. A Review of Studies of Research Opportunities in Energy Conservation. PNL-4571, Pacific Northwest Laboratory, Richland, Washington.

Hopp, W., et al. 1981. An Overview of Energy Conservation Research Opportunities--Executive Summary. PNL-3944 Ex. Sum., Pacific Northwest Laboratory, Richland, Washington.

Hopp, W., et al. 1981. An Overview of Energy Conservation Research Opportunities. PNL-3944, Pacific Northwest Laboratory, Richland, Washington. 
Hopp, W., et a1. 1982. Identification of Energy Conservation Research Opportunities: A Review and Synthesis of the Literature. PNL-3966, Pacific Northwest Laboratory, Richland, Washington.

U.S. Department of Energy. 1981. The 1981 ECUT Work Element Appraisal. DOE/CE-0024, U.S. Department of Energy, Washington, D.C.

U.S. Department of Energy. 1983. Energy Conversion and Utilization Technologies Program Report, 1981-1982. U.S. Department of Energy, Washington, D. $\bar{C}$.

Vallario, R. W. and D. E. DeBellis. 1984. State of Technology of Direct Contact Heat Exchanging. PNL-5008, Pacific Northwest Laboratory, Kichland, Washington.

Vitul10, M., C. Winter and D. R. Johnson. 1984. The Executive Information System. PNL-5190, Pacific Northwest Laboratory, Richland, Washington. 
BACKGROUND ON ECUT ENERGY DATA REFERENCE SERIES

The ECUT Energy Data Reference Series defines and assesses in quantitative terms the potential markets for expected ECUT R\&D results. Each volume in the series provides data on a particular class of hardware systems that use and convert fuel. The data for each system include inventories of energy capital stocks, specific fuels consumption and product or service activity levels for the years 1980 and 2000, and average thermal efficiencies. Each data set characterizes the capital stock in a sector or subsector of the U.S. economy to which expected results from ECUT R\&D projects can be applied. Each reference volume is consistent with the others in the series in format and approach, thus forming a framework for comparing certain aspects of ECUT R\&D activities.

The ECUT Energy Data Reference Series serves as a benchmark for energy consumption and for conservation data for technologies addressed by the ECUT Program. The series incorporates the most accurate and up-to-date projections available in the open literature on energy capital stocks and their consumption levels. The series is specifically intended to be one of the many planning tools ECUT management can use to assess what potential impact its research projects will have. The series can also be used to demonstrate the potential impact of research on various stakeholders and constituencies, including industrial interest groups, budget decision makers, and the general public.

METHODOLOGY

The ECUT Energy Data Reference Series synthesizes data from the open literature, including technical reports, results of techno-economic models, industry surveys, and trade journal publications. A specific format was developed around the data items of interest and the intended purpose of the series. Each volume deals with a unique R\&D application. Two scenarios are described-a baseline for 1980 and a projection for 2000 .

The first line of effort is to extract the most recent data that are already in usable form in the open literature. In the case of competing data from disparate sources, the most reliable data are selected on the basis of the 
completeness and extensiveness of the research. Where data sources appear to be equally reliable, an averaging method is employed to derive a single data point.

The second line of effort is to derive or extrapolate the needed data from the literature. For instance, if no energy consumption data are reported, production data can be multiplied by energy intensity data to derive consumption data.

Certain assumptions are used in projecting data points to the year 2000 . The general rule is that the status quo is maintained throughout the projected future unless otherwise specified in the text. The energy capital stock is assumed to remain at its 1980 state of technology, and no competing technologies are considered to capture market share. This is in keeping with the objective of defining the potential impact of R\&D results. In characterizing systems or processes with multiple fuel inputs, the mix of conventional fuels (those commonly used today) is allowed to change as each fuel is impacted by obvious and compelling factors, but no alternative, non-conventional fuels are projected as part of the fuel mix.

For simplicity, electricity is considered to be a fuel. This allows for a discussion of capital stocks that use electricity as an input without going through the machinations of breaking out power generation inputs, transmission losses, etc. These factors are considered to be constant at the national average, and are readily available in the literature.

SCOPE

The scope is defined along two directions: the data items of interest, and the end-use sector applications for ECUT R\&O activities. The data items of interest, described below, are essential to a basic perspective on the potential impact of expected ECUT R\&D results. Data items that change with time are defined for the year 1980 and projected for the year 2000. 
DATA ITEMS

The data items considered in this series of reports are unit process hardware systems, efficiency estimates, capital stock information, fuel consumption demand, and product or service activity level. Unit Process Hardware System

A unit process hardware system (UPHS) is generally defined as the least extensive configuration of components in a conversion or utilization system to which R\&D results can be applied, and for which efficiency and fuel consumption estimates can be made. A UPHS is uniquely defined for each sector potentially impacted by ECUT R\&D activity.

\section{Efficiency Estimates}

A specific definition of efficiency is developed for each application of each R\&D activity. In general, the definition is based on the first law of thermodynamics, and is applied to the UPHS of interest. A broad discussion of major efficiency-loss mechanisms is included in each section on efficiency.

\section{Capital Stock Information}

Data derived for 1980 and projected for 2000 are based on the number of UPHSs in the economy that would be potential recipients of ECUT R\&D results. UPHSs are disaggregated according to the type of fuel they use or convert. Other factors that help characterize the capital stock as a market for ECUT research are included as necessary and/or available.

\section{Fuel Consumption Demand}

Fuel consumption demand is developed for 1980 and projected for 2000 . The thermal energy value (measured in Btu) of each fuel type consumed or converted by the capital stock of interest is developed for each application of each R\&D activity. Electricity is considered to be a fuel. The extent to which use of alternative (non-conventional) fuels will penetrate the end-use sectors of interest by the year 2000 is not predicted. The relative contribution of conventional fuels in use today is, however, allowed to change with the turnover of capital stocks and with trends in consumer preferences. No attempt is made to project the availability of conventional fuels in 2000 . 
Product or Service Activity Level

Data on the demand for each product or service resulting from the use or conversion of energy by the capital stock of UPHSs are developed for 1980 and projected for 2000 . 


\section{SUMMARY}

This report summarizes information that describes the use of hightemperature materials in advanced heat engines for ground transportation applications. Applications discussed in this report are:

- automobiles

- light trucks

- medium and heavy trucks.

The information provided on each of these modes includes descriptions of the average conversion efficiency of the engine, the capital stock, the amount of energy used, and the activity level as measured in ton-miles. This information is summarized in Tables $S .1$ and S.2. 
TABLE S.1. Research and Development Applications Summary

\begin{tabular}{|c|c|c|c|c|c|c|c|c|}
\hline & & $\begin{array}{c}\text { UPHS } \\
\text { Average } \\
\text { Efticlency }\end{array}$ & $\begin{array}{c}\text { Unlt } \\
\text { Hardware }\end{array}$ & $\begin{array}{l}\text { rocesss } \\
\text { Systems }\end{array}$ & $\begin{array}{l}\text { Fue I Con } \\
\text { Demand }\end{array}$ & $\begin{array}{l}\text { umption } \\
\text { (Btu) }\end{array}$ & $\begin{array}{r}\text { Prod } \\
\text { Service AC } \\
\text { iton- } \\
\end{array}$ & $\begin{array}{l}\text { it or } \\
\text { ivity Level } \\
\text { les) }\end{array}$ \\
\hline & Dato_Item/Fuel Type & & 1980 & 2000 & 1980 & 2000 & 1980 & 2000 \\
\hline & AUTOWOBILES & & & & & & & \\
\hline & Gesoline & $26 \%$ & $104,564,000$ & $110,000,000$ & $9,740 \times 10^{12}$ & $7,050 \times 10^{12}$ & $2,060 \times 10^{9}$ & $1,910 \times 10^{9}$ \\
\hline & LIGHT TRUCKS & & & & & & & \\
\hline & Gasollne & $26 \%$ & $28,900,000$ & $33,300,000$ & $2,717 \times 10^{12}$ & $2.82 \times 10^{12}$ & $877,000,000$ & $1,063,000,000$ \\
\hline & LPG & 268 & 87,000 & 108,000 & $7.25 \times 10^{12}$ & $7.55 \times 10^{12}$ & $2,600,000$ & $3,620,000$ \\
\hline & MEDILM AND HEAVY & & & & & & & \\
\hline & TRUCK5 & & & & & & & \\
\hline & Gasoline & $26 \%$ & $3,575,000$ & $3,293,000$ & $651 \times 10^{12}$ & $600 \times 10^{12}$ & $221 \times 10^{9}$ & $169 \times 10^{9}$ \\
\hline & LPG & 264 & 10,760 & 9,930 & $4.0 \times 10^{12}$ & $4.4 \times 10^{12}$ & $555 \times 10^{6}$ & $425 \times 10^{6}$ \\
\hline
\end{tabular}


TABLE S.2. Market Data Summary

Item/Fuel Type AUTOMOBILES

Gasoline
LIGHT TRUCKS

Gasollne

LPG

MEDIUM AND HEAVY

\section{TRUCKS}

Gasoll ne

LPG

\section{UPHS Due}

to Industry

Total Totol Projected Capoclty ExpanSlon (Increased Hardware Systems Hardware Systems Servlce Demand) 1980

2000

\begin{tabular}{l} 
IUPHS Due to UPHS from \\
Replacement of \\
Obsolete Units \\
\hline
\end{tabular}

2000

$\frac{\text { In Servlce }}{2000}$

$104,564,000$

$110,000,000$

$-5,436,000$

$101,4 \pi, 000$

$3,136,920$

$28,900,000$

$33,300,000$

87,000

108,000

$4,400,000$

21,000

$28,370,000$

85.400

532,000

1.650

$3,575,000$

$3,293,000$

9.930

$-$

$2,399,000$

7,240

894,000

2,690 


\section{CONTENTS}

ACKNOWLEDGMENTS.

PREFACE

..................................................

BACKGROUND ON ECUT ENERGY DATA REFERENCE SERIES................ ix

SUMMARY. $x i j i$

1.0 HIGH-TEMPERATURE MATERIALS FOR ADVANCED hEAT ENGINES........... 1.1

1.1 STIRLING ENGINES............................ 1.2

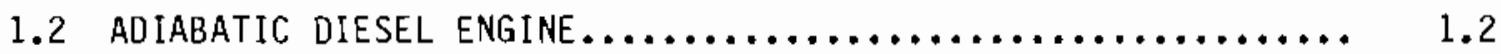

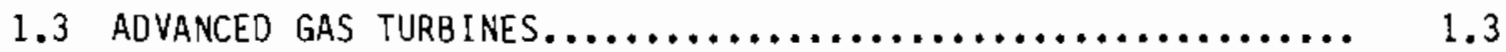

2.0 HIGH-TEMPERATURE MATERIALS FOR ADVANCED HEAT ENGINES IN

AUTOMOBILES ................................... 2.1

2.1 EFFICIENCY ESTIMATES......................... 2.1

2.1 .1 Loss Mechanisms......................... 2.4

2.2 CAPITAL STOCK INFORMATION..................... 2.7

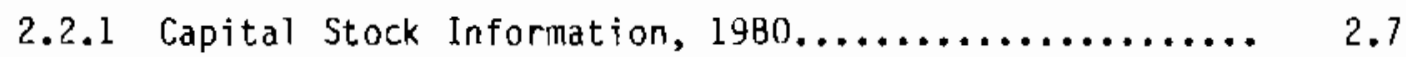

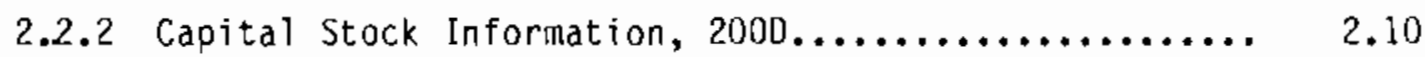

2.3 FUEL CONSUMPTION DEMAND....................... 2.13

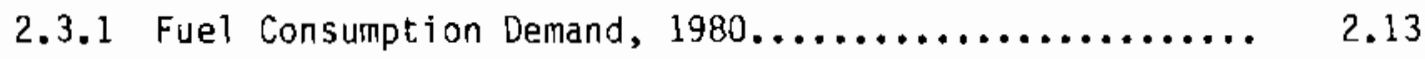

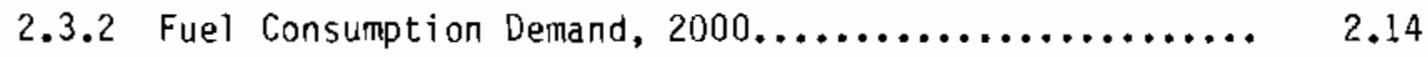

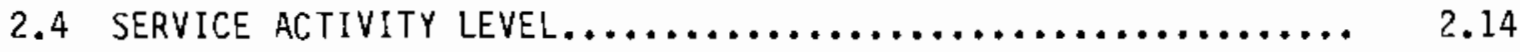

2.4.1 Service Activity Level, 1980................. 2.14

2.4.2 Service Activity Level, 2000................. 2.15

3.0 LIGHT TRUCKS.................................. 3.1

3.1 EFfiCIENCY ESTIMATE.......................... 3.2

3.2 CAPITAL STOCK INFORMATION...................... 3.3

3.2 .1 Capital Stock Information, $1980 \ldots \ldots \ldots \ldots \ldots \ldots \ldots \ldots . \ldots . \ldots . \ldots$ 
3.2 .2 Capital Stock Information, $2000 \ldots \ldots \ldots \ldots \ldots \ldots \ldots \ldots . . \ldots .4$

3.3 FUEL CONSUMPTION DEMAND....................... 3.5

3.3.1 Fuel Consumption Demand, $1980 \ldots \ldots \ldots \ldots \ldots \ldots \ldots \ldots \ldots . . \ldots . . . \ldots$

3.3 .2 Fuel Consumption Demand, $2000 \ldots \ldots \ldots \ldots \ldots \ldots \ldots \ldots \ldots .6 .6$

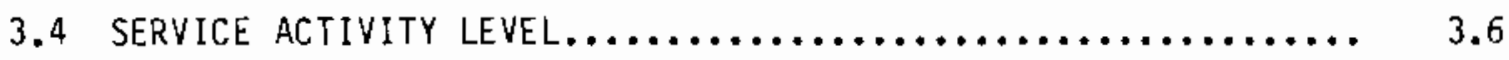

3.4.1 Service Activity Level, 1980................. 3.6

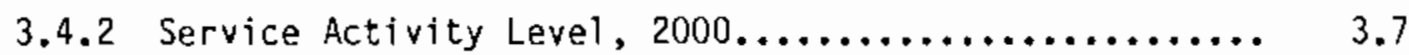

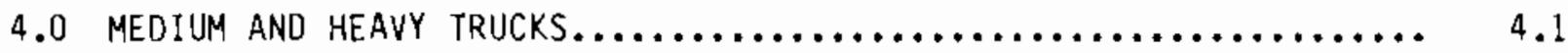

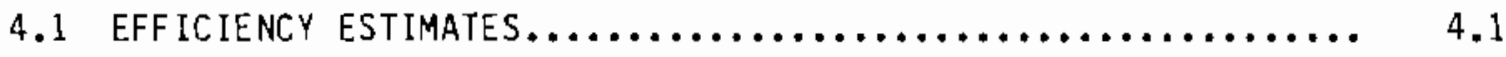

4.2 CAPITAL STOCK INFORMATION....................... 4.2

4.2.1 Capital Stock Information, $1980 \ldots \ldots \ldots \ldots \ldots \ldots \ldots . . \ldots \ldots .2$

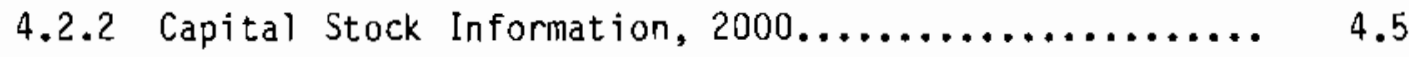

4.3 FUEL CONSUMPTION DEMAND......................... 4.5

4.3.1 Fuel Consumption Demand, $1980 \ldots \ldots \ldots \ldots \ldots \ldots \ldots \ldots \ldots . . \ldots . \ldots$

4.3 .2 Fuel Consumption Demand, $2000 \ldots \ldots \ldots \ldots \ldots \ldots \ldots \ldots .4 .6$

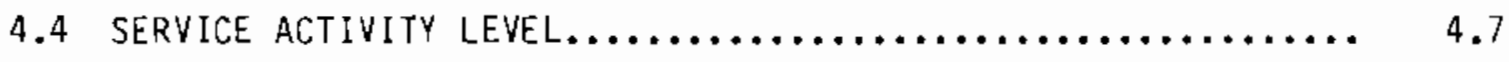

4.4.1 Service Activity Level, $1980 \ldots \ldots \ldots \ldots \ldots \ldots \ldots \ldots \ldots \ldots$............. 4

4.4 .2 Service Activity Level, $2000 \ldots \ldots \ldots \ldots \ldots \ldots \ldots \ldots \ldots .4 .7$

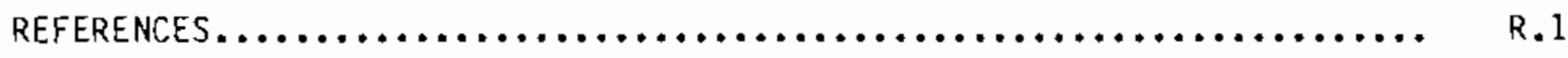




\section{FIGURES}

1.1 Experimental Piston Design for a Ceramic-Type Adiabatic Diesel Engine...................................... 1.6

1.2 AGT-100 Ceranic Parts Under Development................... 1.7

2.1 Energy Use in Passenger Car During EPA Cycle................ 2.2

2.2 Projected Specific Fuel Consumption of the AGT 101 at Various Stages of Development............................... 2.4

2.3 Comparison of Brake Specific Fuel Consumption of Various Engines.. 2.5

2.4 Automotive Fuel Economy Standards, 1967 to $1985 . \ldots \ldots \ldots \ldots \ldots . . . . .2 .6$

2.5 Projected Vehicle Fuel Economy of the AGT 101 Compared to the Diesel- and Gasoline-Powered Vehicles..................... 2.7

2.6 Comparison of the Energy Balance Between Basic and Adiabatic Diesel Engines..................................... 2.8

2.7 Survival Probability Curves for Automobiles and Light Trucks..... 2.10

4.1 Fuel Consumption Rates for Local Gasoline-Powered Vehicles by Gross Vehicle Weight Rating............................ 4.3 


\section{TABLES}

S.1 Research and Development Applications Summary................ xiv

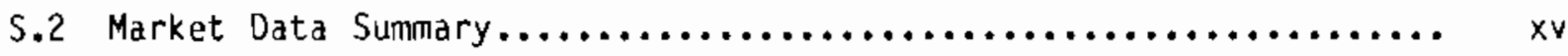

1.1 Alloys Presently Used and Alternatives Under Evaluation for the Automotive Stirling Engine.............................. 1.3

1.2 Meater Tube Alloys Under Evaluation for the Automotive Stirling Engine............................................ 1.4

1.3 Cylinder Head and Regenerator Housing Materials Under Evaluation for the Automotive Stirling Engine................. 1.5

1.4 Materials Under Evaluation for Ceramic-Type Adiabatic Diesel Engine Hot Components....................................... 1.5

2.1 Automobile Stock in 1980 by Size Category $\ldots \ldots \ldots \ldots \ldots \ldots \ldots \ldots .2 .8$

2.2 Motor Vehicles in Use, Sales, and New Registration in the

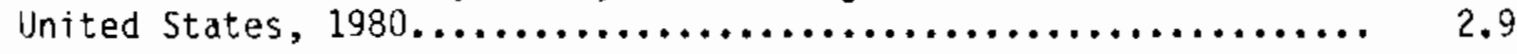

2.3 Market Shift in Automobile Sales Between 1978 and $1980 . \ldots \ldots \ldots . .2 .10$

2.4 Automobiles in Operation, Scrappage Rates, and Vehicle

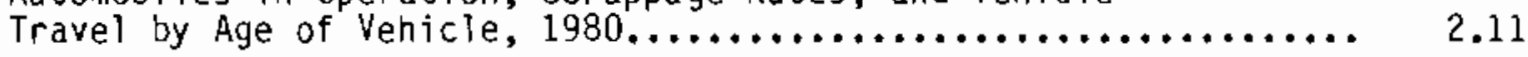

2.5 Projections of Automobile Stock in $2000 \ldots \ldots \ldots \ldots \ldots \ldots \ldots \ldots \ldots . .2 .12$

2.6 Summary of Projected Automobile Ownership, Use, and Energy Demand............................................... 2.13

3.1 Truck Categories by Vehicle Weight $\ldots \ldots \ldots \ldots \ldots \ldots \ldots \ldots \ldots \ldots . . .1$

3.2 Comparison of Fuel Economy Estimates for Light Trucks in 1980.... 3.3

3.3 Comparison of Stock Projections for Light Trucks............... 3.3

3.4 Comparison of Energy-Use Projections for Light Trucks........... 3.5

3.5 Projected Changes in the Use of Light Trucks................. 3.7

4.1 Comparison of Truck Fuel Economy by Gross Vehicle Weight......... 4.2

4.2 Comparison of Stock Projections for All Medium and Heavy Trucks... 4.3

4.3 Estimated and Projected Otto Engine Truck Stock by Size Category $\ldots \ldots \ldots \ldots \ldots \ldots \ldots \ldots \ldots \ldots \ldots \ldots \ldots \ldots \ldots \ldots \ldots \ldots \ldots \ldots \ldots \ldots, 4.4$ 
4.4 Domestic and Imported Truck Sales in $1980 \ldots \ldots \ldots \ldots \ldots \ldots \ldots \ldots \ldots . . \ldots 4$

4.5 Estimated 0tto Cycle Truck Sales in $1980 . \ldots \ldots \ldots \ldots \ldots \ldots \ldots \ldots \ldots . . \ldots 4$

4.6 Comparison of Energy-Isse Projections for Medium and Heavy Trucks.. 4.5

4.7 0tto Engine Truck Energy Consumption in $1980 \ldots \ldots \ldots \ldots \ldots \ldots \ldots \ldots$

4.8 Projected 0tto Engine Truck Energy Consumption in 2000........ 4.7

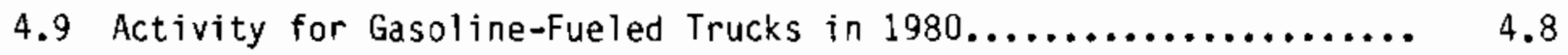

4.10 Percentage Distribution of Truck Energy Consumption by Major

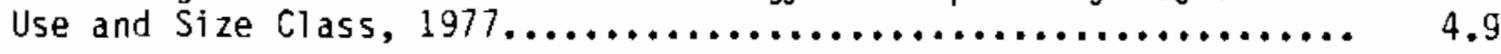

4.11 Activity for Gasoline- and LPG-Fueled Trucks in 2000.......... 4.10 


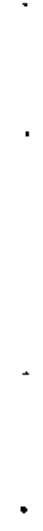




\subsection{HIGH-TEMPERATURE MATERIALS FOR ADVANCED HEAT ENGINES}

A number of alternative concepts for automotive propulsion are being considered to replace the otto cycle engine. These alternative propulsion systens include the following:

- Stirling engine

- automotive gas turbine

- adiabatic diesel engine.

These concepts are currently being researched and developed to be equal or superior to the presently used 0tto cycle engines in terms of perforinance, fuel economy and cost. In addition, the advanced heat engines are expected to have low exhaust emissions, to have low levels of noise and vibration, and to use alternative fuels.

These advanced heat engines must operate at temperatures and pressures nigher than conventional automotive engines. This combination (high pressure, high temperature and highly erosive/corrosive engine environinents) presents severe materials property requirements that may not even be met by currently available technology. Examples of expected operating conditions are:

- for the Stirling engines, temperatures of $820^{\circ} \mathrm{C}\left(1508^{\circ} \mathrm{F}\right)$ or higher at the heater head and maximum hydrogen pressure of $20 \mathrm{MPa}$ (2899 psi)

- for the automotive gas turbine, turbine inlet temperatures expected to be greater than $1150^{\circ} \mathrm{C}\left(2100^{\circ} \mathrm{F}\right)$, possibly as much as $1260^{\circ} \mathrm{C}$ $\left(2300^{\circ} \mathrm{F}\right)$

- for the adiabatic diesel engine, peak combustion temperature of $1200^{\circ} \mathrm{C}\left(2200^{\circ} \mathrm{F}\right)$ and a peak combustion pressure of $13.8 \mathrm{MPa}$ (2000 psi) occurring over high frequency stress cycles.

The candidate advanced materials that can operate under the severe conditions expected of the advanced heat engines include:

- structurar ceranics

- long-range ordered alloys

- intermetallic compounds (e.g., aluminides)

- superalloys. 
The temperature limits for these advanced materials are roughly as follows:

- ceramics - greater than $1100^{\circ} \mathrm{C}$

- long-range ordered alloys and intermetallics - up to $1100^{\circ} \mathrm{C}$

- superalloys - up to $900^{\circ} \mathrm{C}$.

Specific applications of advanced materials are discussed in the following sections:

\subsection{STIRLING ENGINES}

The heater tubes, cylinder heads, regenerator housings, and piston domes are the hot-end components of the Stirling engine that are critical. Table 1.1 lists the materials currently used for the components in the prototype and the alternative materials selected for investigation. The composition for heat tube materials (wrought alloys) and for cylinder head and regenerator housing materials (cast alloys) is given in Tables 1.2 and 1.3 , respectively. Specific areas for R\&D in materials include hydrogen permeation, environmental effects on mechanical properties and development of advanced processing techniques that lead to reduced manufacturing cost.

\subsection{ADIABATIC DIESEL ENGINE}

The materials used for the hot components of the adiabatic diesel engine (ADE) must be able to retain strength over a long period of time while operating at the high pressures and temperatures occurring over high frequency stress cycles. The current design of the ADE considers the use of both ceramic and metallic materials for the hot section components.

Some of the ceramic materials under evaluation for the critical components are listed in Table 1.4. An experimental piston design using a ceramic piston cap with an aluminum metal base is shown in Figure 1.1 .

There are difficulties associated with design and manufacture using structural ceramics; these include degradation due to environmental attack and due to local stress concentrations at superficial point contracts. Also, engine design is frequently complicated by a need to use thermal barriers to reduce heat losses. 
TABLE 1.1. Alloys Presently Used and Alternatives Under Evaluation for the Automotive Stirling Engine (Liu 1981)

\begin{tabular}{|c|c|c|c|}
\hline \multicolumn{2}{|r|}{ Component } & $\begin{array}{l}\text { Materials Currently } \\
\text { Used in the } P-40 \\
\end{array}$ & $\begin{array}{c}\text { Alternative Materials } \\
\text { Under Evaluation }\end{array}$ \\
\hline & Heater Tubes & $N-155$ & $\begin{array}{l}\text { XN-520 (Climax Molybdenum) } \\
\text { Inconel } 625,718 \\
\text { Inconel } X-750 \\
\text { Incoloy } 901,800 \mathrm{H} \\
\text { Sandvik } 12 \text { RN } 72 \\
\text { Sanicro } 32 \mathrm{X} \\
\text { Sanicro } 31 \mathrm{H} \\
\text { Avesta } 253 \mathrm{MA} \\
\text { 19-9DL } \\
\text { HS-188 } \\
\text { A-286 } \\
\text { Nitronic } 40\end{array}$ \\
\hline 2. & $\begin{array}{l}\text { Cylinder Heads } \\
\text { and Regenerator } \\
\text { Housings }\end{array}$ & HS-31 & $\begin{array}{l}\text { XF }-818 \text { (C1 imax Mo Tybdenum) } \\
\text { CRM-60 } \\
\text { SAF }-11\end{array}$ \\
\hline 3. & Piston Domes & $\begin{array}{l}\mathrm{N}-155 \text {, Nimonic } 80 \mathrm{~A} \\
\text { machined from bar }\end{array}$ & $\begin{array}{l}\text { Inconel } 718 \text {, deep drawn or } \\
\text { hydraulically formed sheet }\end{array}$ \\
\hline
\end{tabular}

An alternative approach to the use of structural ceramics is to use metallic materials coated with thermal barriers. The components being evaluated are:

- pistons where base metal is coated with yttrium-stabilized zirconia

- cast alloy cylinder head and lining coated with insulating materials such as zirconia and chromium oxides

- stainless steel exhaust manifold coated with zirconia.

\subsection{ADVANCED GAS TURB INES}

Advanced gas turbines (AGT) must operate at temperatures distinctly higher than conventional piston engines if they are to achieve the desired performance goals. Unfortunately, state-of-the-art materials, both ceramic and metallic, do not have adequate anisotropic or directional strength and corrosion resistance to perform under the required severe operating conditions. Improved. ceramic parts are the probable material of choice in the internal hot sections 
TABLE 1.2. Heater Tube Alloys Under Evaluation for the Automotive Stirling Engine (Liu 1981)

\begin{tabular}{|c|c|c|c|c|c|c|c|c|c|c|c|c|c|c|c|c|}
\hline Alloy & C & $M n$ & S1 & $\mathrm{Cr}$ & $\mathrm{N} 1$ & Co & Mo & $w$ & To+Nb & At & Y & $B$ & $\mathrm{Zr}$ & TI & $\mathrm{Fe}$ & Other \\
\hline$x N-520$ & 0.05 & 0.5 & 0.1 & 20.0 & Bal & & 5.0 & 5.0 & 2.0 & 1.0 & 0.05 & 0.005 & 0.05 & 0.2 & & \\
\hline $\begin{array}{l}\text { Inconel } 625 \\
\text { Inconel } 718 \\
\text { Inconel } x-750\end{array}$ & $\begin{array}{l}0.05 \\
0.04 \\
0.04\end{array}$ & $\begin{array}{l}0.5 \\
0.2 \\
0.5\end{array}$ & $\begin{array}{l}0.25 \\
0.2 \\
0.25\end{array}$ & $\begin{array}{l}21.0 \\
18.5 \\
16.0\end{array}$ & $\begin{array}{l}\mathrm{Bal} \\
\mathrm{Bal} \\
\mathrm{Bal}\end{array}$ & & $\begin{array}{l}9.0 \\
3.0\end{array}$ & & $\begin{array}{l}3.7 \\
5.1 \\
1.0\end{array}$ & $\begin{array}{l}0.2 \\
0.5 \\
0.65\end{array}$ & & & & $\begin{array}{l}0.2 \\
0.9 \\
2.5\end{array}$ & $\begin{array}{r}2.5 \\
18.5 \\
7.0\end{array}$ & \\
\hline $\begin{array}{l}\text { Incoloy } 901 \\
\text { Incoloy } \mathrm{BOOH}\end{array}$ & $\begin{array}{l}0.05 \\
0.01\end{array}$ & $\begin{array}{l}0.5 \\
0.7\end{array}$ & $\begin{array}{l}0.3 \\
0.5\end{array}$ & $\begin{array}{l}12.5 \\
22.5\end{array}$ & $\begin{array}{l}42.0 \\
32.6\end{array}$ & & 6.0 & & & $\begin{array}{l}0.2 \\
0.54\end{array}$ & & 0.015 & & $\begin{array}{l}2.7 \\
0.52\end{array}$ & $\begin{array}{l}\mathrm{BaI} \\
\mathrm{BaI}\end{array}$ & \\
\hline $12 \mathrm{RN} 72$ & 0.10 & 1.8 & 0.4 & 19.0 & 25.0 & & 1.4 & & & & & 0.006 & & 0.5 & & \\
\hline $\begin{array}{l}\text { Sanlero } 32 x \\
\text { Sanlcro } 31 \mathrm{H}\end{array}$ & $\begin{array}{l}0.09 \\
0.07\end{array}$ & $\begin{array}{l}0.6 \\
0.6\end{array}$ & $\begin{array}{l}0.6 \\
0.6\end{array}$ & $\begin{array}{l}21.0 \\
21.0\end{array}$ & $\begin{array}{l}31.0 \\
31.0\end{array}$ & & & 3.0 & & $\begin{array}{l}0.4 \\
0.3\end{array}$ & & & & $\begin{array}{l}0.4 \\
0.3\end{array}$ & $\begin{array}{l}\text { Bal } \\
\text { Bal }\end{array}$ & \\
\hline NItron $1 \mathrm{c} 400$ & 0.03 & 9.4 & 0.49 & 20.8 & 1.0 & & & & & & & & & & Bal & $0.34 \mathrm{~N}$ \\
\hline $253 \mathrm{MA}$ & $0.0 B$ & 0.08 & & 21.0 & 11.0 & & & & & & & & & & & $0.17 \mathrm{~N}$ \\
\hline A-286 & 0.06 & 1.01 & 0.6 & 14.4 & 24.7 & & 1.2 & & & & & & & 2.1 & & $0.3 \mathrm{Cu}, 0.26 \mathrm{v}$ \\
\hline $19-9 \mathrm{DL}$ & 0.30 & 1.00 & 0.50 & 19.0 & 9.0 & & 1.4 & 1.3 & 0.4 & & & & & 0.30 & Bal & \\
\hline$\$ 155$ & 0.12 & 1.5 & 0.50 & 21.0 & 20.0 & 19.0 & 3.0 & 2.5 & 1.0 & & & & & & Bal & \\
\hline $\mathrm{HS}-18 \mathrm{~B}$ & 0.10 & 1.25 & 0.3 & 22.0 & 22.0 & $\mathrm{Bal}$ & & 14.0 & & & & & & & 3.0 & $0.04 \mathrm{La}$ \\
\hline
\end{tabular}


TABLE 1.3. Cylinder Head and Regenerator Housing Materials Under Evaluation for the Automotive Stirling Engine (Liu 1981)

\begin{tabular}{|c|c|c|c|c|c|c|c|c|c|c|c|c|c|c|c|}
\hline Alloy & C & Mn & Si & $\mathrm{Cr}$ & NI & co & Mo & $W$ & $\mathrm{Ta}+\mathrm{Nb}$ & Al & $Y$ & B & $\mathrm{Zr}$ & $\mathrm{Fe}$ & Other \\
\hline $\begin{array}{l}\mathrm{HS}-31 \\
(\mathrm{X}-40)\end{array}$ & 0.5 & 0.5 & 0.5 & 25.0 & $\overline{10.0}$ & $\overline{54.0}$ & & $\overline{7.5}$ & & & $\overline{0.5}$ & & $\overline{0.9}$ & & \\
\hline$X F-81 B$ & 0.21 & 0.12 & 0.28 & 18.0 & 17.9 & & 7.6 & & 0.4 & & & 0.75 & 0.003 & Bal & $0.115 \mathrm{~N}$ \\
\hline $\mathrm{CPM}-60$ & 1.05 & 5.0 & 0.5 & 22.0 & 5.0 & & 1.0 & 1.0 & 1.0 & & & 0.003 & & $\mathrm{Bal}$ & \\
\hline
\end{tabular}

SAF-11

Composition not known

TABLE 1.4. Materials Under Evaluation for Ceramic-Type Adiabatic Diesel Engine Hot Components (Liu 1981)

\begin{tabular}{|c|c|}
\hline Component & Materials Under Evaluation \\
\hline Piston cap & $\begin{array}{l}\text { Hot-pressed silicon nitride (HPSN) } \\
\text { Sintered silicon nitride (SSN) } \\
\text { Reaction-bonded silicon nitride (RBSN) } \\
\text { Sintered silicon carbide (SSC) } \\
\text { Partially stabilized zirconia (PSZ) }\end{array}$ \\
\hline Bolt fastener & $\begin{array}{l}\text { Waspaloy } \\
\text { Udimet } 700 \\
\text { R-41 }\end{array}$ \\
\hline Cylinder head hot plate & $\begin{array}{l}\text { Hot-pressed silicon nitride (HPSN) } \\
\text { Sintered silicon nitride (SSN) } \\
\text { Zirconia }\end{array}$ \\
\hline Deck spacer ring & $\begin{array}{l}\text { Hot-pressed silicon nitride (HPSN) } \\
\text { Sintered silicon nitride (SSN). } \\
\text { Zirconia }\end{array}$ \\
\hline Cylinder liner & $\begin{array}{l}\text { Hot-pressed silicon nitride (HPSN) } \\
\text { Sintered silicon nitride } \\
\text { Partially stabilized zirconia (PSZ) }\end{array}$ \\
\hline Exhaust manifold & $\mathrm{ZrO}_{2}$-coated stainless steels \\
\hline
\end{tabular}

of the AGT because of their potential for high temperature capability. Ceramics are preferred because their constituents are lightweight, readily available and inexpensive as compared to imported strategic elements contained in current superalloys.

Although ceramic parts have been strengthened significantly, failures of static ceramic components still frequently occurred during rig and engine tests. These failures appear to be induced by contact stresses or transient 


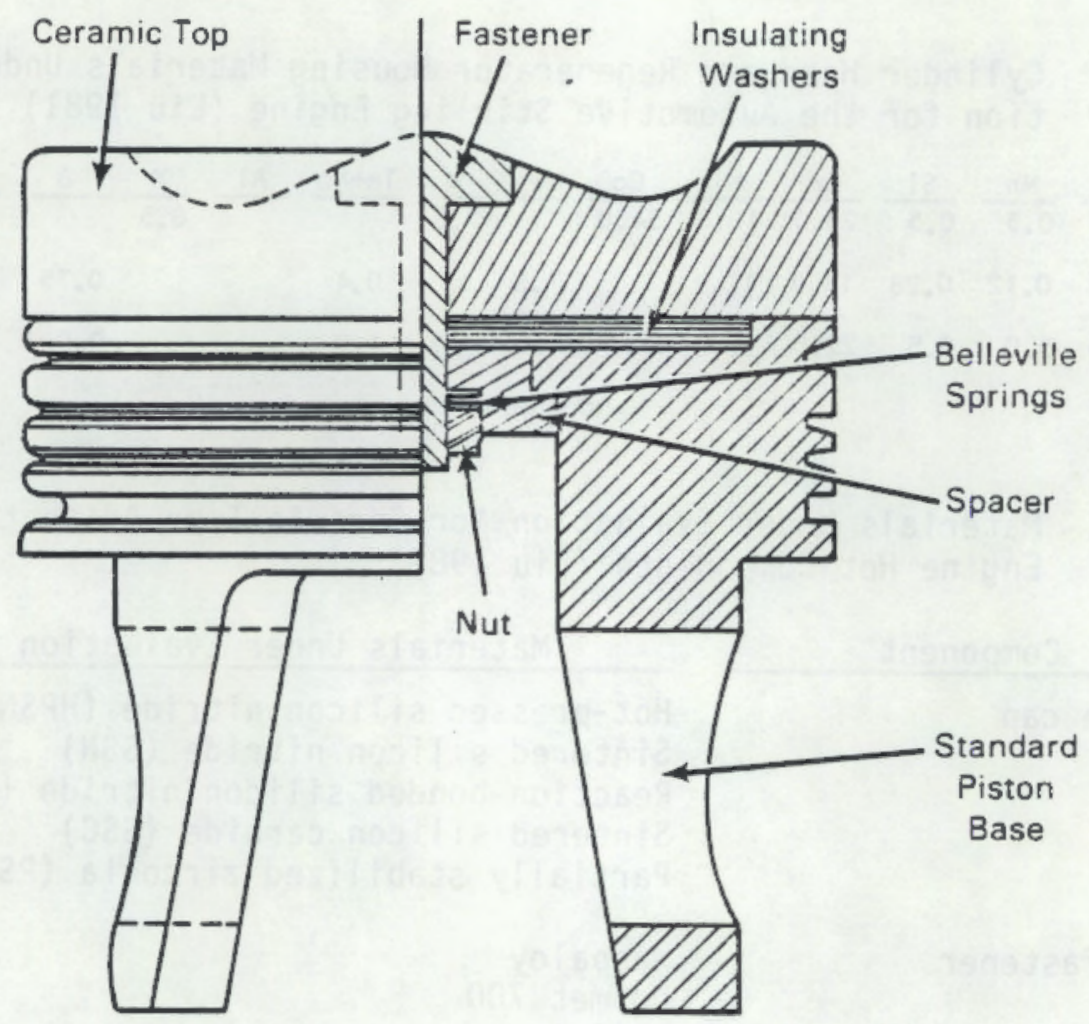

FIGURE 1.1. Experimental Piston Design for a Ceramic-Type Adiabatic Diesel Engine (Bryzik 1978)

thermal stresses during start-up. Use of structural ceramics for turbine blades has been more successful because of the more uniform temperatures to which turbine blades are exposed. Controlling fabrication procedures and identifying flaws are two major technical barriers that can be addressed by materials research.

Figure 1.2 shows the ceramic components being considered for the GM AGT-100 engine. Metallic materials with ceramic thermal barriers such as yttria-stabilized zirconia are frequently used for static components such as plenum assemblies and vanes. Use of lamalloy and transpiration cooling are other means available to improve the performance of AGT components.

With a significant amount of adaptation, materials technology presently available may allow the advanced heat engines to capture a little of the potential for increased efficiency offered by operation at increased temperature and 


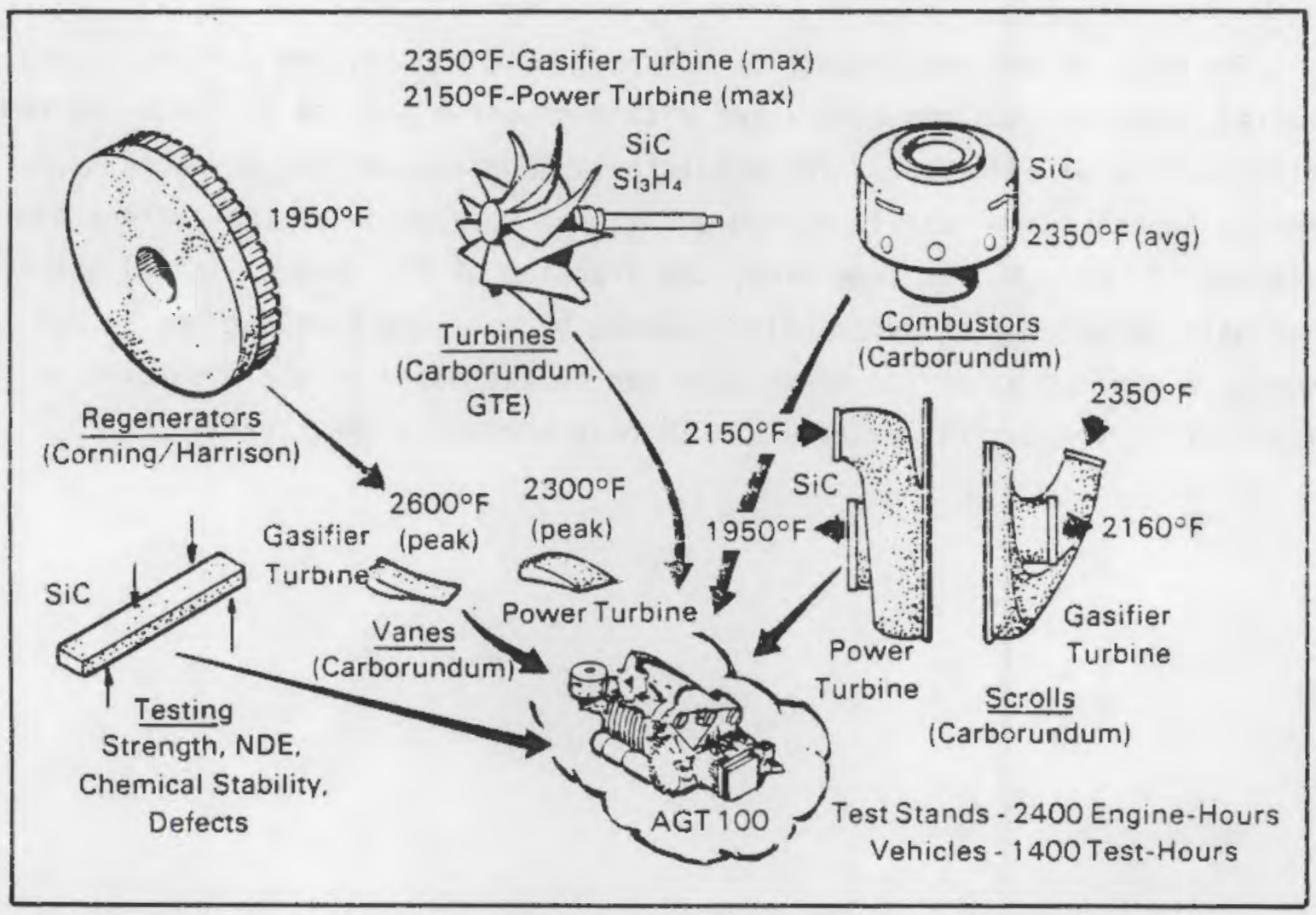

FIGURE 1.2. AGT-100 Ceramic Parts Under Development (D0E 1980)

pressure. However, it is only through the successful development of the desirable properties and the feasibility for mass production of the materials that the greatest potential for engine efficiency improvements will be realized.

The principal difficulty in assessing the energy impact of alternative automotive engines is the fact that projections of the future characteristics of the transportation system are based on historical data and trends. This is complicated by the lack of data on the performance of the alternative engine concepts. The references used to develop the data were prepared during the period 1974-1979 when there was a strong consensus that alternative automotive engines were needed. Data from reports earlier than 1974 were considered dated because they were based on historical trends (1974 and prior years) that do not reflect more current trends (1976 to the present). The automobile has since undergone radical changes in terms of both the configuration (size and power availability) and sales. 
The data on the performance of advanced heat engines are currently very limited, and the problems associated with production and use of these engines still have to be addressed. The projected performance of the advanced heat engines depends very heavily on the successful completion of the current and recommended $R \& D$. At the same time, the fraction of the future capital stock that will be made up of automobiles powered by advanced heat engines is not known. A minimum sales for these cars can be estimated at the breakeven point of capturing the capital expenditure in mass producing these cars. 


\subsection{HIGH-TEMPERATURE MATERIALS FOR ADVANCED HEAT ENGINES IN AUTOMOBILES}

The advanced engine concepts being researched and developed are anticipated to compete with currently used Otto and diesel cycle engines for automotive propulsion. The impact of R\&D in advanced engine concepts can be assessed from its anticipated share of the future capital stock and the concomitant improvement in energy use in transportation.

On the other hand, research in high-temperature materiais does not affect energy use in the transportation sector directly, but has indirect effect through the use of advanced engine concepts as alternative automotive propulsion systems. Research and development can overcome materials limitations that impede the development of advanced engine concepts and these concepts can subsequently be established as viable alternatives to the otto and diesel cycle engines.

The analysis of the impact of research in high-temperature materials in transportation should then be conducted by consideration of the following:

- technical impact

- market impact.

The technical impact addresses the technical barriers to full implementation of advanced heat engines. Research on high-temperature materiais seeks to overcome the limitations of operation at high pressures and temperatures that are characteristic of currently available materials. The technical impact of hightemperature materials research is discussed in the sections that follow.

The market impact can be assessed by assuming that all technical barriers to the use of advanced engine concepts in transportation are overcome and they are able to capture their potential share of the market and the future capital stock. Advanced engine concepts will compete in the same market defined for ot to and diesel cycle engines in transportation.

\subsection{EFFICIENCY ESTIMATES}

The various ways by which the efficiency of energy conversion in automotive transportation systems can be estimated is shown in Figure 2.1. For a 


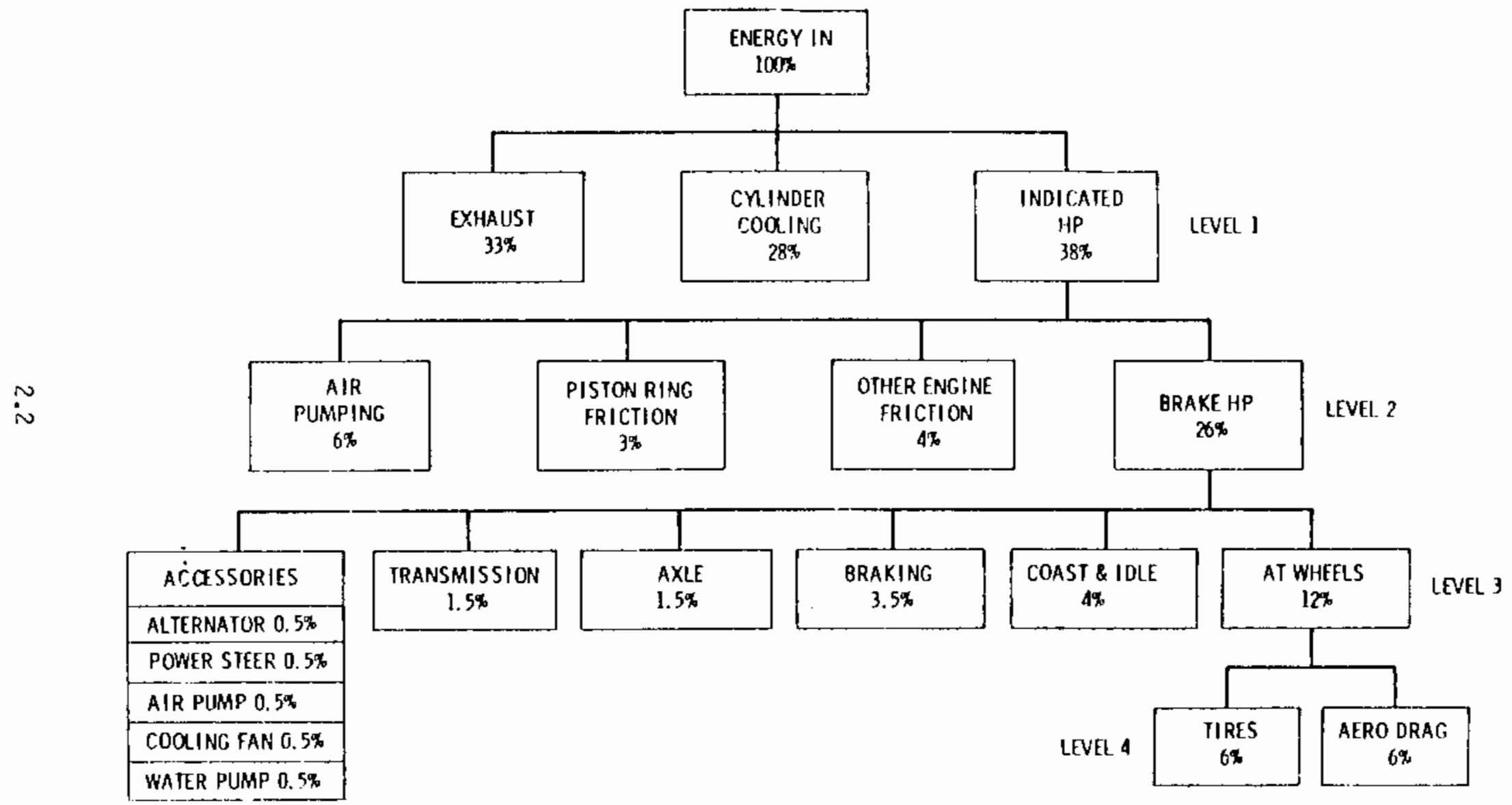

FIGURE 2.1. Energy Use in Passenger Car During EPA Cycle (Hopp 1981) 
passenger car using a state-of-the-art 0tto cycle engine, the thermal efficiencies during an EPA specified driving cycle are as follows:

- The indicated thermal efficiency is $38 \%$. This represents the conversion of input energy into work done against the piston through the expansion of the combustion gases. The theoretical thermal efficiency is close to this vaive.

- The brake thermal efficiency is $25 \%$. This represents the conversion of the input energy into work delivered by the power shaft of the engine.

The brake specific fuel consumption (bsfc) is a commonly used basis for comparing alternative propulsion systems. The bsfc provides a measure of the amount of fuel used $(1 \mathrm{~b} / \mathrm{hr}$ ) to deliver one brake horsepower (bhp) at the output shaft. It can be noted that the brake thermal efficiency is inversely related to the bsfc (i.e., lower bsfc results in higher brake thermal efficiencies) and can be calculated from the bsfc upon inclusion of the heating value of the fuel. Figure 2.2 shows expected improvements in specific fuel consumption of the AGT 101. The turbine inlet temperature tolerance is raised by incorporation of additional and improved ceramic turbine parts at the various stages of development of the advanced gas turbine. Increase in the turbine inlet temperature allows for an improvement in the bsfc as well as in the net power output of the turbine. In Figure 2.3 the bsfc of various engine types is compared.

When the engine is used in a complete transportation system, such as an automobile, added factors such as weight and speed are introduced. In this case, passenger car fuel economy in miles per gallon of fuel consumed (mpg) makes a more appropriate measure for comparison; it is also a measure more readily understood by car buyers. The automotive fuel economy standards for the years 1967 to 1980 and the EPA projected fuel economy standards to 1985 are shown in Figure 2.4. The new car fuel economy for 1980 (calculated using manufacturers' sales projections) is 22.4 mpg compared to on-road new car fuel economy based on actual sales data of $20.4 \mathrm{mpg}$. It can be noted that estimates of new car fuel economy based on sales projections markedly exceed the EPA fuel economy standards for 1980. On-road new car fuel economy, however, has just 


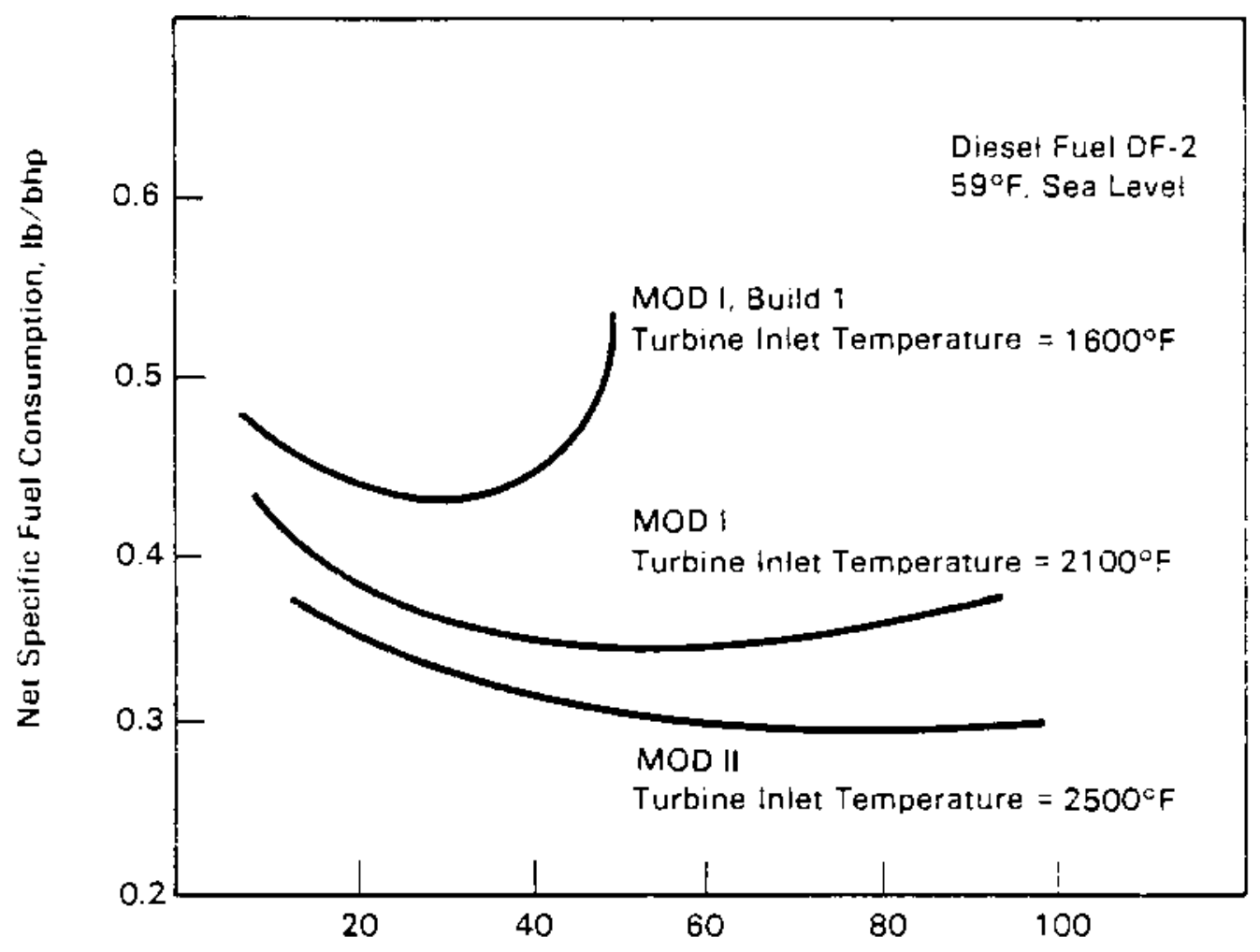

Net Engine Output Power, bhp

FIGURE 2.2. Projected Specific Fuel Consumption of the AGT 101 at Various Stages of Development (Garrett/Ford 1981)

barely surpassed the fuel economy standard of $20.0 \mathrm{mpg}$ for 1980 . The fuel economy expected of advanced heat engines used in automobiles will have to be compared to the out-year mpg values in Figure 2.4 .

In Figure 2.5 the projected fuel economy of the Garrett/Ford advanced gas turbine (AGT 101) is compared to the fuel economy of diesel- and gasolinepowered vehicles for various vehicle inertia weights. The potential improvement over the current AGT vehicle is also shown.

\subsubsection{Loss Mechanisins}

An estimate of the energy distribution in a typical passenger car powered by an otto cycle engine has been shown in Figure 2.1. As indicated in Figure 2.1, there are four levels at which improvements in energy conversion can be made. Replacement of currently used engines with advanced heat engines will 


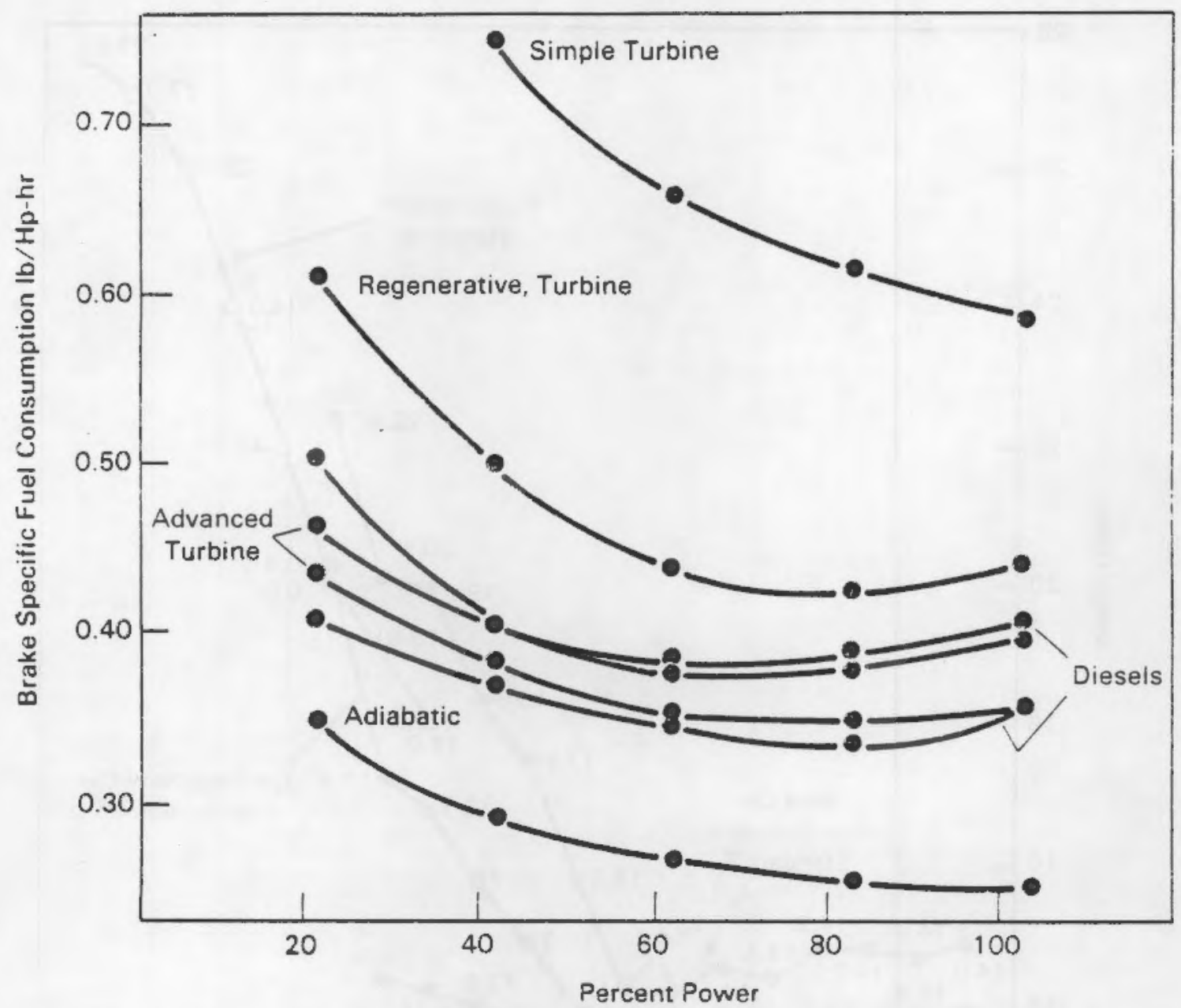

FIGURE 2.3. Comparison of Brake Specific Fuel Consumption of Various Engines (G1ance 1979)

achieve improvements at Level 1 and 2. A new engine concept (Stirling thermodynamic cycle versus 0tto thermodynamic cycle) will introduce improvements at Level 1, while actual hardware developed (prototype or mass-produced engines) will effect changes at Level 2.

A comparison of the energy distribution between a basic turbocharged diesel engine and an adiabatic diesel engine (ADE) with turbocompounding is shown in Figure 2.6. The ADE exhibits an improvement of fuel economy from the $0.36 \mathrm{lb} / \mathrm{bhp}-\mathrm{hr}$ of the basic diesel engine to $0.285 \mathrm{lb} / \mathrm{bhp}-\mathrm{hr}$, and increases power by more than $30 \%$ for the same fuel input. 


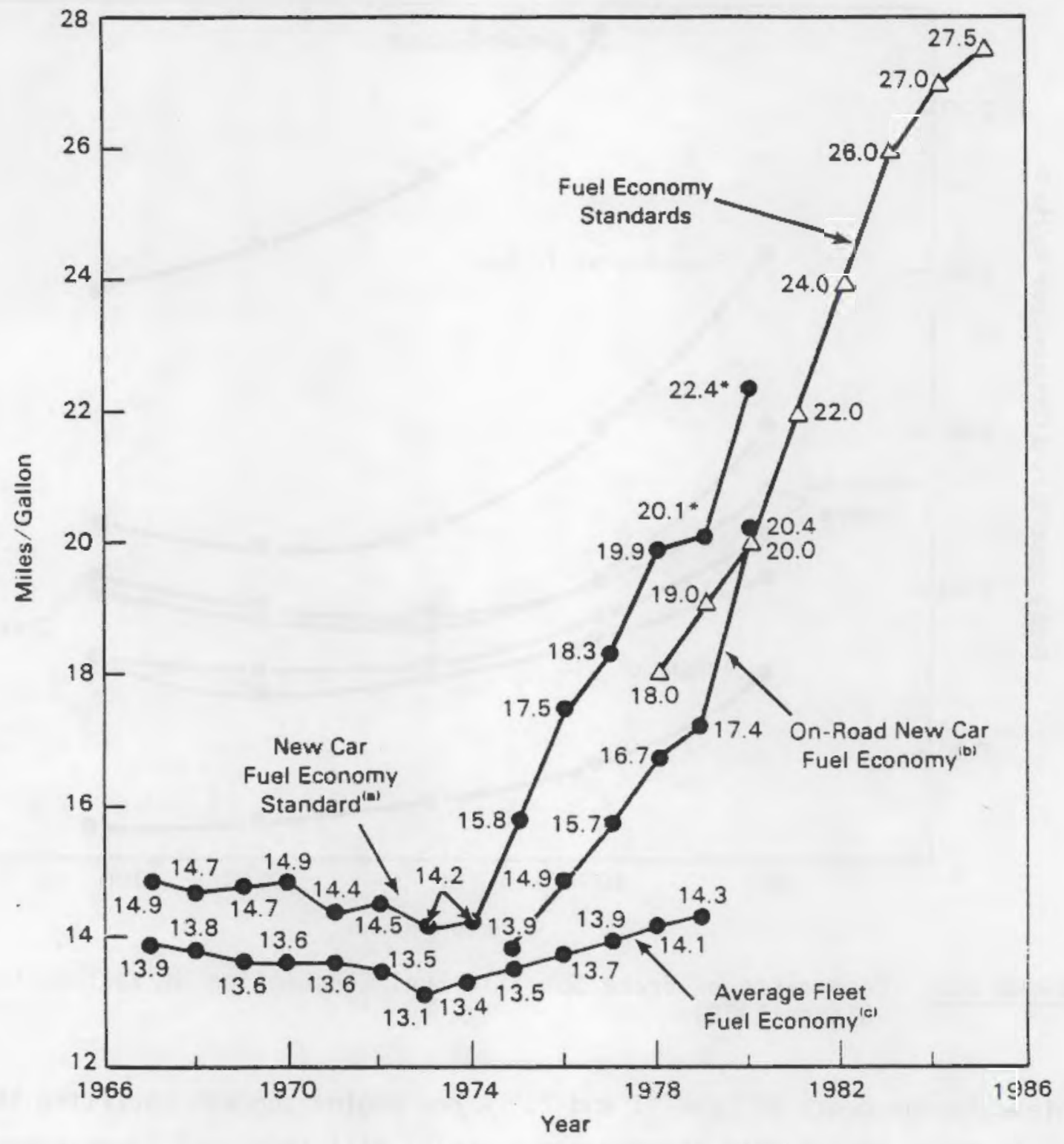

"Based on manufacturers' sales projection

J.D. Murrell, J.A. Foster, and D.M. Bristor, Environmental Protection Agency,

Passenger Car and Light Truck Fuel Economy Trends through 1980. SAE Paper 800853.

${ }^{\circ}$ Catculated using EPA fuel economy values. It should be noted that EPA new car fuel economy values for 1979 and 1980 are calculated using manufacturers' sales projections, while the on-road new car fuel economy is based on actual sales data. The source for the on-road fuel economy is: Energy and Environmental Analysis, Inc., The Highway Fuel Consumption Model - Fourth Quarterly Report, prepared for the U.S. Department of Energy, Washington, D.C., July 1981.

'U.S. Department of Transportation, Federal Highway Administration, Highway Statistics, Washington, D.C., annual.

FIGURE 2.4. Automotive Fuel Economy Standards, 1967 to 1985 (Oak Ridge 1981) 


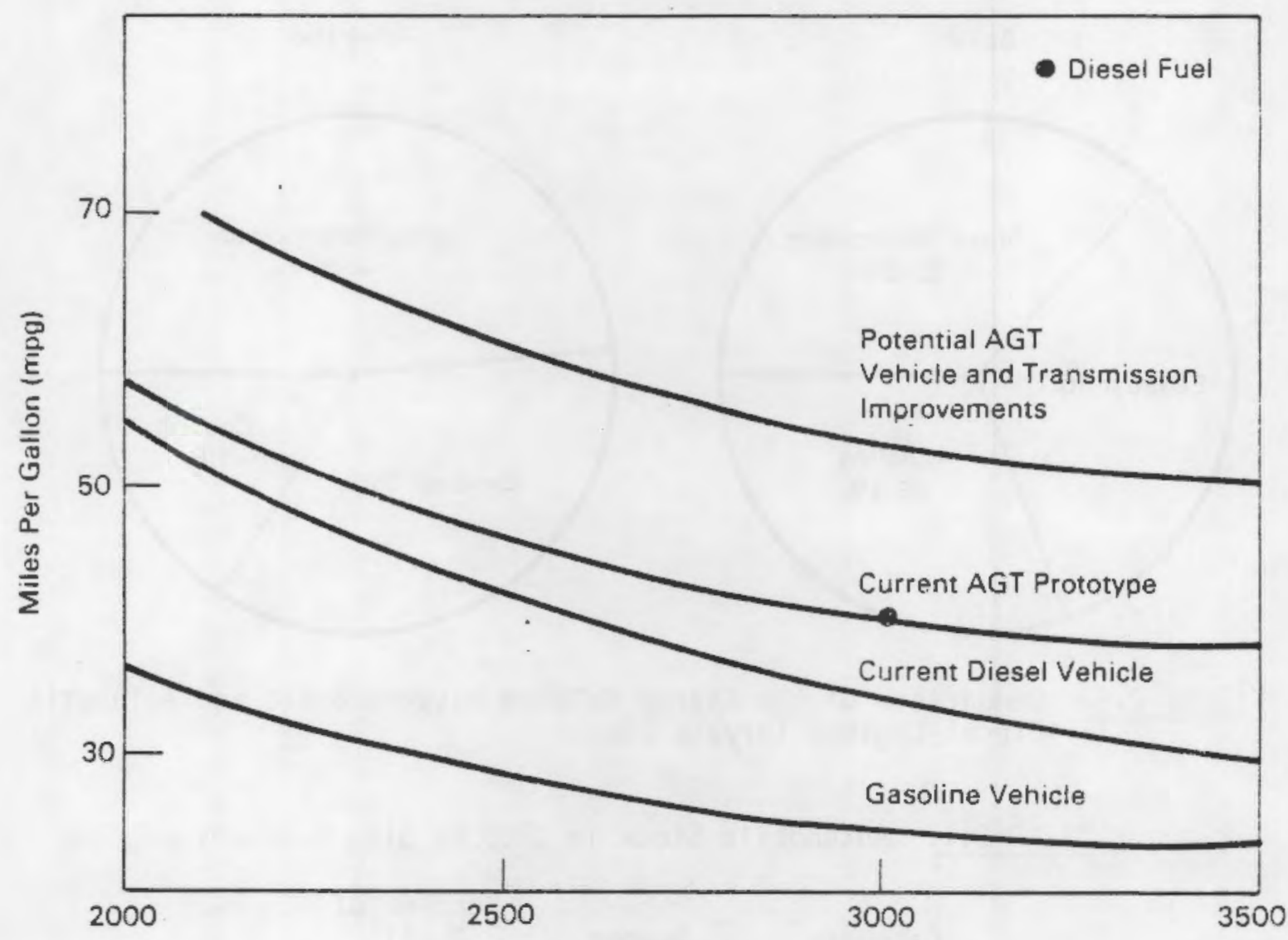

Vehicle Inertia Weight

FIGURE 2.5. Projected Vehicle Fuel Economy of the AGT 101 Compared to the Diesel- and Gasoline-Powered Vehicles (Garrett/Ford 1981)

\subsection{CAPITAL STOCK INFORMATION}

\subsubsection{Capital Stock Information, 1980}

Oak Ridge (1981) estimates that there were 104,564,000 automobiles in use in 1980. The breakdown of automobiles among the six categories of vehicles is shown in Table 2.1 .

Information describing the sales of domestic and imported automobiles in 1980 is shown in Table 2.2. The table shows that subcompact cars had the 1argest share of the market at $38.0 \%$, with midsize following at $33.7 \%$, and large cars third at $13.4 \%$. This is a notable market shift from 1978 when midsize had the largest share of the market at $31.6 \%$, followed by large and subcompact 

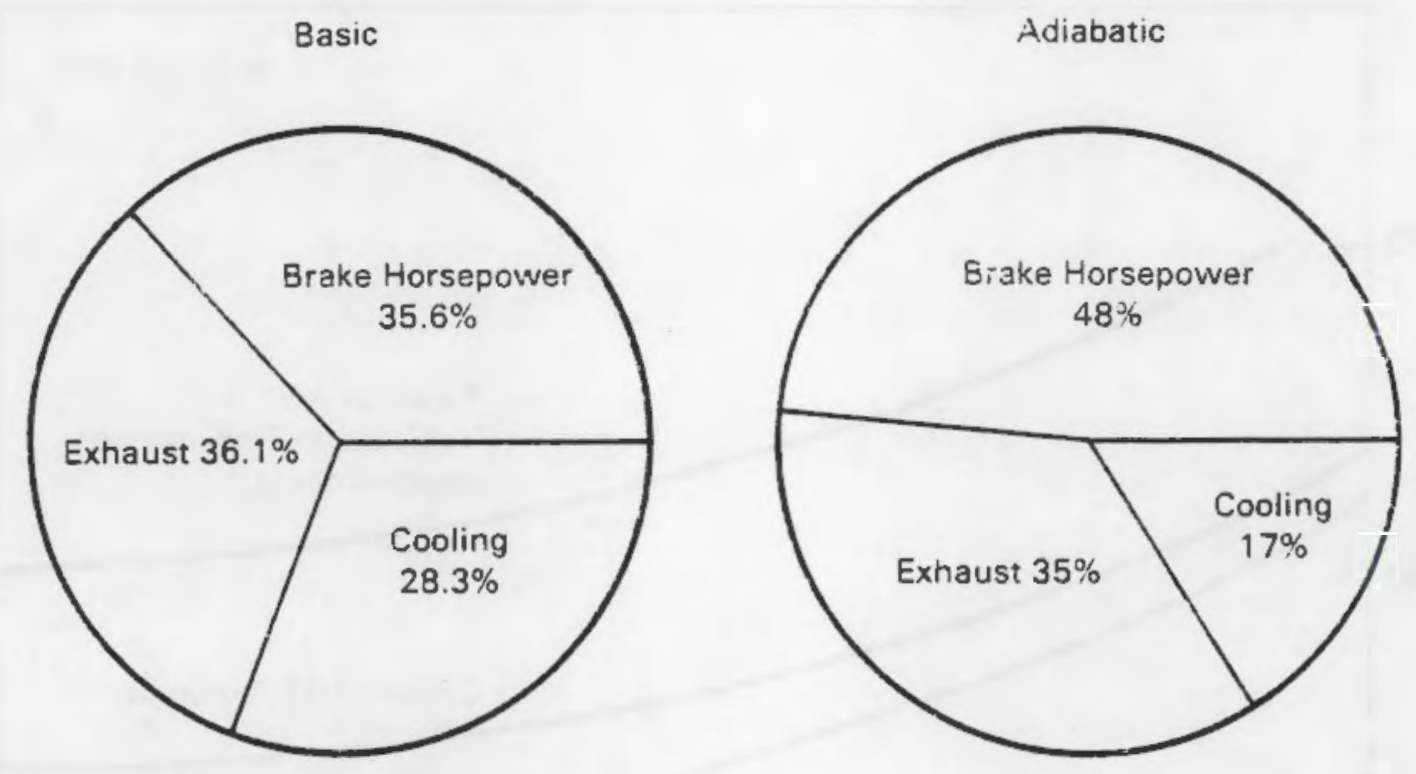

FIGURE 2.6. Comparison of the Energy Balance Between Basic and Adiabatic Diesel Engines (Bryzik 1980)

TABLE 2.1. Automobile Stock in 1980 by Size Category

\begin{tabular}{lrrrr}
\cline { 1 - 1 } Category & & Number & & $\begin{array}{c}\text { Percent } \\
\text { Total }\end{array}$ \\
\cline { 1 - 1 } Mino seater & & $1,687,000$ & & $1.6 \%$ \\
Subcompact & & $20,042,000$ & & $19.2 \%$ \\
Compact & & $15,772,000$ & & $15.1 \%$ \\
Midsize & & $25,471,000$ & & $24.4 \%$ \\
Large & & $34,582,000$ & & $33.1 \%$
\end{tabular}

cars, which had $20 . \%$ and $19.9 \%$ of the market, respectively. A comparison of the market shift between 1978 and 1980 is provided in Table 2.3.

Information on the survival and scrappage rates of automobiles is illustrated in Figure 2.7 and Table 2.4. The survival probability curve for automobiles as a function of their age is shown in Figure 2.7. One can see from the figure that the "half-life" for automobiles is approximately 10 years. Points on the curve are tabulated in Table 2.4, which also presents information on scrappage rates, the number of vehicles in operation, and the percent of vehicle miles traveled (by age group). 
TABLE 2.2. Motor Vehicles in Use, Sales, and New Registration in the United States, 1980 (0ak Ridge 1981)

\begin{tabular}{|c|c|c|c|c|c|c|c|}
\hline & \multirow{3}{*}{$\begin{array}{l}\text { Motor Vehicles } \\
\text { in Use as of } \\
\text { July } 1,1980 \\
\text { (in thousands) } \\
\end{array}$} & \multicolumn{6}{|c|}{ Sales } \\
\hline & & \multicolumn{2}{|c|}{ Domestic } & \multicolumn{2}{|c|}{ Imported (a) } & \multicolumn{2}{|c|}{ Total } \\
\hline & & (in thousands) & $\begin{array}{l}\text { Percentage } \\
\text { Domestic }\end{array}$ & (in thousands) & $\begin{array}{c}\text { Percentage } \\
\text { Import } \\
\end{array}$ & (in thousands) & $\begin{array}{l}\text { Percentage } \\
\text { by Class }\end{array}$ \\
\hline $\begin{array}{l}\text { Autambiles } \\
\text { Two seater } \\
\text { Minicampact } \\
\text { Subcampact } \\
\text { Compact } \\
\text { Midsize } \\
\text { Large }\end{array}$ & $\begin{array}{r}104,564 \\
1,687 \\
7,010 \\
20,042 \\
15,772 \\
25,471 \\
34,582\end{array}$ & $\begin{array}{c}6,369(\mathrm{~b}) \\
37 \\
169 \\
1,444 \\
533 \\
2,993 \\
1,193\end{array}$ & $\begin{array}{r}100.0 \\
0.6 \\
2.6 \\
22.7 \\
8.4 \\
47.0 \\
18.7\end{array}$ & $\begin{array}{r}2,527 \\
179 \\
234 \\
1,936 \\
175 \\
3 \\
0\end{array}$ & $\begin{array}{r}100.0 \\
7.1 \\
9.3 \\
76.6 \\
6.9 \\
0.1 \\
0.0\end{array}$ & $\begin{array}{r}8,896 \\
216 \\
403 \\
3,330 \\
708 \\
2,996 \\
1,193\end{array}$ & $\begin{array}{r}100.0 \\
2.4 \\
4.5 \\
38.0 \\
8.0 \\
33.7 \\
13.4\end{array}$ \\
\hline $\begin{array}{l}\text { Fleet }(4+) \\
\text { Personal }\end{array}$ & $\begin{array}{l}10,433(c) \\
94,131\end{array}$ & & & & & & \\
\hline Motorcycles & 7,400 & 130 & 10.4 & 1,120 & 89.6 & 1,250 & 100.0 \\
\hline Mopeds & 1,000 & (d) & & (d) & & 210 & 100.0 \\
\hline Recreational vehicles & 6,000 & $308^{(e)}$ & 100.0 & 0 & 0.0 & 308 & 100.0 \\
\hline $\begin{array}{l}\text { Trucks }(f) \\
\text { Light } \\
\text { Light-Heavy/Heavy-Heavy }\end{array}$ & $\begin{array}{r}35,268 \\
30,119 \\
2,116 \\
y \quad 1,093\end{array}$ & $\begin{array}{r}2,035 \\
1,765 \\
6 \\
89\end{array}$ & $\begin{array}{r}100.0 \\
86.7 \\
0.3 \\
4.4\end{array}$ & $\begin{array}{l}485 \\
480 \\
5(9)\end{array}$ & $\begin{array}{l}100.0 \\
99.0 \\
1.0(\mathrm{~g})\end{array}$ & $\begin{array}{c}2,520 \\
2,245 \\
6 \\
269(\mathrm{~g})\end{array}$ & $\begin{array}{c}100.0 \\
89.1 \\
0.2 \\
10.7(9)\end{array}$ \\
\hline
\end{tabular}

(a) Includes captive imports - Autombiles: Arrow Champ, Sapporo, Colt, Challenger, Fiesta, and Opel. Trucks: Ohevrolet LWN, Ford Courier, Plymarth Arrow, and Dodge 060.

(b) Total does not include some 32,785 special purpose vehicles (AMC Eagle), which are classified with trucks.

(c) Includes federal government vehicles.

(d) Not available.

(e) Shiprents only.

(f) Includes vans and special purpose vehicles; also AMC Eagle. Before MN 1980, passenger vans were included with automobile sales data.

(g) Includes heavy-heavy. 
TABLE 2.3. Market Shift in Automobile Sales Between 1978 and 1980

(0ak Ridge 1981)

\begin{tabular}{|c|c|c|c|}
\hline \multirow[b]{2}{*}{ Category } & \multicolumn{3}{|c|}{$\begin{array}{l}\text { Market Share of Sales } \\
\text { (in percent) }\end{array}$} \\
\hline & 1978 & $\underline{1979}$ & 1980 \\
\hline Two seater & 1.2 & 0.9 & 2.4 \\
\hline Minicompact & 12.8 & 5.0 & 4.5 \\
\hline Subcompact & 19.9 & 33.1 & 38.0 \\
\hline Compact & 14.0 & 9.3 & 8.0 \\
\hline Mid size & 31.6 & 37.5 & 33.7 \\
\hline Large & 20.8 & 19.5 & 13.4 \\
\hline
\end{tabular}

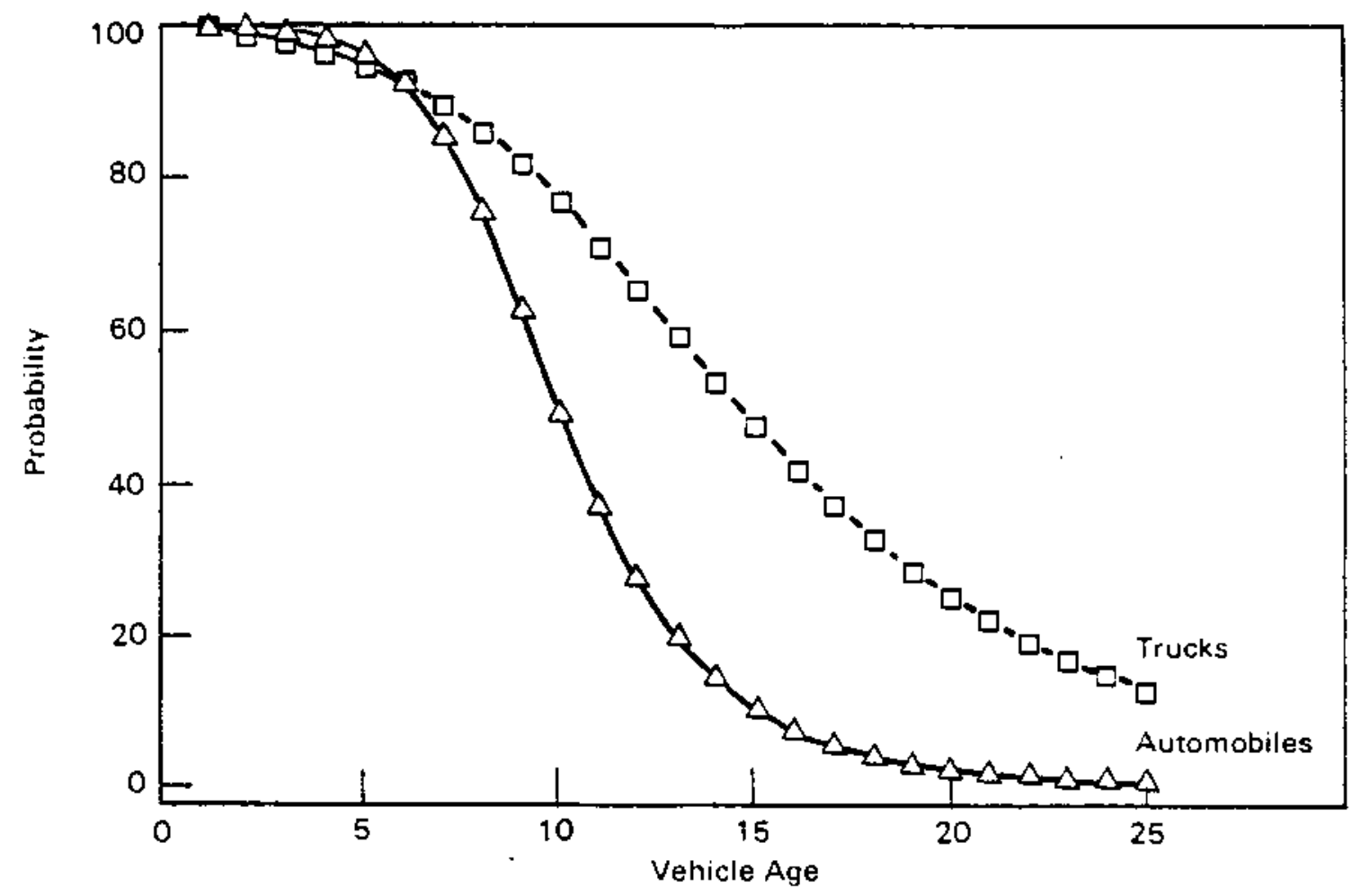

FIGURE 2.7. Survival Probability Curves for Automobiles and Light Trucks (Oak Ridge 1981)

\subsubsection{Capital Stock Information, 2000}

Since 1975, several models have been assembled to predict characteristics of the automobile stock and energy use up to the year 2000. Among the organizations performing the modeling were the Office of Technology Assessment, the 
TA8LE 2.4. Automobiles in Operation, Scrappage Rates, and Vehicle Travel by Age of Vehicle, 1980 (Oak Ridge 1981)

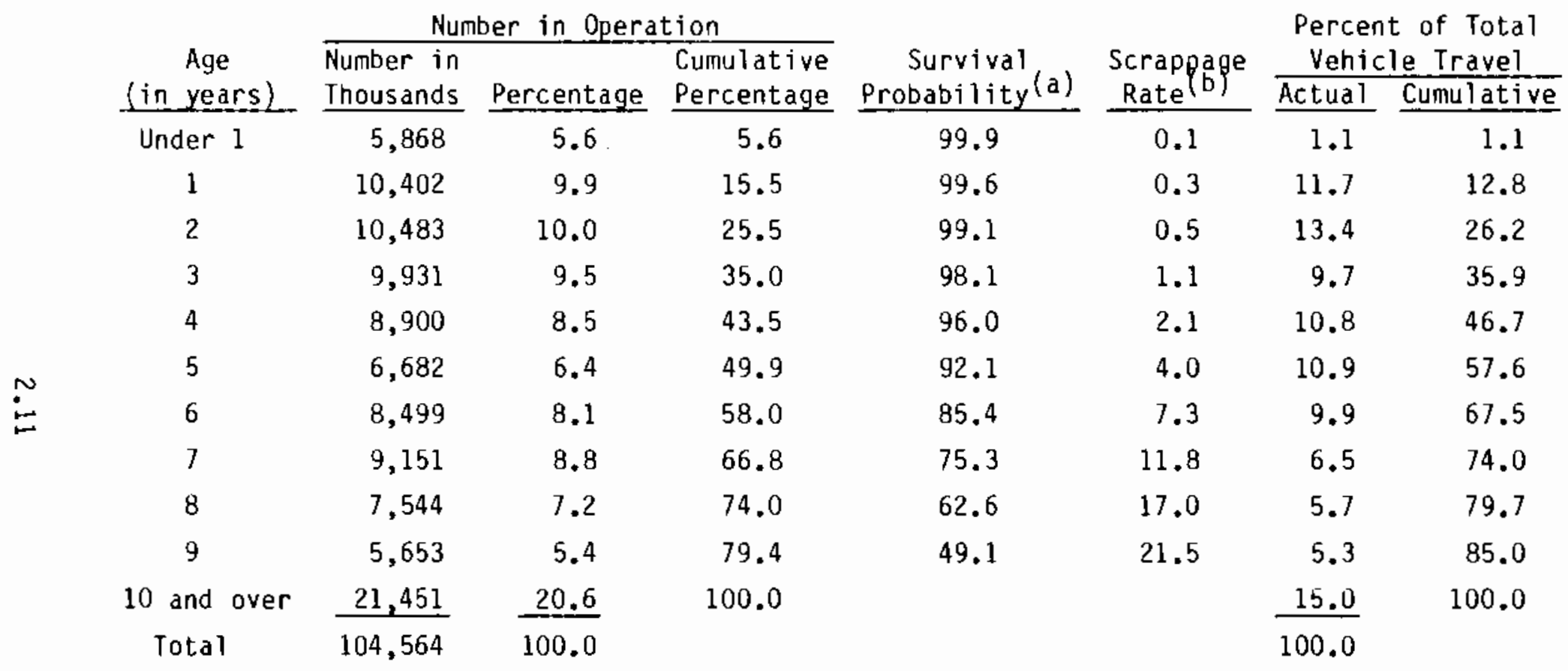

(a) The probability that a vehicle of a certain type in a given class will be "in use" (registered) in a given year.

(b) Percentage of vehicles of a certain type in a given age class that are retired from use (lacking registration) in a given year. 
Wharton School, Argonne National Laboratory, the DOE Office of Policy Planning and Analysis, the DOT Transportation Systems Center, Oak Ridge National Laboratory, Energy and Environmental Analysis, Inc., and Data Resources, Inc. The results of these projections are shown in Table 2.5. Automobile stock in the year 2000 is projected to range from 131 million vehicles to 153 million vehicles, with the values averaging around $140 \mathrm{million}$ automobiles (see Table 2.5). The annual growth rates ranged from $1.2 \%$ to $1.9 \%$.

The Office of Technology Assessment (OTA) developed two scenarios for the changes in Otto and diesel engine use in automobiles. In Case $A$, the penetration of diesel engines was assumed to be $10 \%$ of new car sales in 1985 and $25 \%$ of new car sales in 2000. In Case B, the penetration of diesel engines was assumed to be $15 \%$ and $40 \%$ of new car sales for those same years. Combining these scenarios with an anticipated stock of 112 million autos in 1985 and $140 \mathrm{million}$ autos in 2000 (average values from the forecasts) yields the vehicle and energy-use information given in Table 2.6. In Case A, approximately $110 \mathrm{million}$ of the automobiles would be powered by gasoline engines and in Case $B$ the number would be approximately 96 million. The Case A proportions are in fair agreement with Argonne's (Millar et al. 1982) estimate that 82.4\% of the automobile stock in 2000 will be using 0tto cycle engines, $17.4 \%$ diesel engines, and $0.2 \%$ other means of propulsion.

\section{TABLE 2.5. Projections of Automobile Stock in 2000 (Knorr} and Millar 1979, Millar et al. 1982)

\begin{tabular}{lcc}
\multicolumn{1}{c}{ Source of Projection } & & $\begin{array}{c}\text { Estimated } \\
\left(\times 10^{6}\right)\end{array}$ \\
${$\cline { 1 - 1 }$} }$ & 148 \\
Jet Propulsion Laboratory & 143 \\
Wharton School & 146 \\
Argonne National Laboratory & 136 \\
Office of Policy Planning and Analysis & 131 \\
Transportation Systems Center & 136 \\
Oak Ridge National Laboratory & 147 \\
Energy and Environimental Analysis, Inc. & 133 \\
Data Resources, Inc. & 139
\end{tabular}


TABLE 2.6. Summary of Projected Automobile Ownership, Use, and Energy Demand

\begin{tabular}{|c|c|c|c|}
\hline & 1980 & Case A & Case 8 \\
\hline Automobiles in operation (millions) & 104.5 & 140 & 140 \\
\hline Automobile vehicle miles traveled (trillions) & 1.11 & 1.69 & 1.69 \\
\hline $\begin{array}{l}\text { Annual new car sales (millions) } \\
\text { Percent of Diesels }\end{array}$ & $\begin{array}{l}8.9 \\
5\end{array}$ & $\begin{array}{l}16 \\
25\end{array}$ & $\begin{array}{l}16 \\
40\end{array}$ \\
\hline $\begin{array}{l}\text { New car fuel economy (mpg) } \\
\text { EPA standard (a) } \\
\text { Attained-actual driving }\end{array}$ & $\begin{array}{l}20.0 \\
20.4\end{array}$ & $\begin{array}{l}27.5 \\
25.0\end{array}$ & $\begin{array}{l}35.0 \\
29.8\end{array}$ \\
\hline $\begin{array}{l}\text { Fleet fuel economy (mpg) } \\
\text { Attained-actual driving }\end{array}$ & 14.3 & 24.6 & 28.0 \\
\hline $\begin{array}{l}\text { Annual fleet fuel consumption rate } \\
\text { (billions of gallons) } \\
\text { Gasoline } \\
\text { Diesel }\end{array}$ & $\begin{array}{r}79.4 \\
0.6 \\
\end{array}$ & $\begin{array}{l}56.4 \\
12.3 \\
\end{array}$ & $\begin{array}{l}42.9 \\
17.5 \\
\end{array}$ \\
\hline Total & 78.0 & 68.7 & 60.4 \\
\hline $\begin{array}{l}\text { Fleet fuel consumption } \\
\text { (millions of barrels per day) }\end{array}$ & 5.1 & 4.5 & 3.9 \\
\hline
\end{tabular}

(a) The EPA certification value for a particular car is the weighted average of performance in the EPA urban cycle ( $55 \%$ weight) and rural cycle ( $45 \%$ weight).

Factors that will affect the accuracy of the projections include the penetration of light-duty diesel engines, the price of gasoline, and shifting consumer preference between large and small automobiles.

2.3. FUEL CONSUMPTION DEMAND

\subsubsection{Fuel Consumption Demand, 1980}

Argonne (Millar et al. 1982) estimates that in 1980 automobiles consumed approximately 77.9 billion gallons of gasoline, or $9,740 \times 10^{12}$ Btu. By comparison, Oak Ridge (19B1) estimates 79.4 billion gallons were consumed, or $9,930 \times 10^{12} \mathrm{Btu}$, accounting for $44.3 \%$ of the energy used in transportation. The Argonne values will be used here because they appear to be more consistent with other estimates of energy use. 
The most recent data available on military automobile energy use indicate that $1.9 \times 10^{12}$ Btu (15.2 million gallons) of gasoline were used in 1979 .

\subsubsection{Fue? Consumption Demand, 2000}

The OTA scenarios will also be used to project fuel consumption. In Case $A$, diesel-powered automobiles are assumed to be $10 \%$ of new car sales in 1985 and $25 \%$ of new car sales in 2000. The EPA fleet fuel economy standard is assumed to rise to $27.5 \mathrm{mpg}$ by 1985 and remain constant until 2000. In Case $B$, diesel engines are assumed to capture 15\% of new car sales in 1985 and $40 \%$ by 2000. The EPA fleet fuel economy standard is assumed to increase from $27.5 \mathrm{mpg}$ in 1985 to $35.0 \mathrm{mpg}$ in 2000 .

For Case A, the projected automobile gasoline consumption in 2000 is 56.4 billion gallons, or 7.05 quads of gasoline energy. In Case $B$, the projected consumption is 42.9 billion gallons, or 5.36 quads.

\subsection{SERVICE ACTIVITY LEVEL}

\subsubsection{Service Activity Level, 1980}

In 1980, automobiles traveled 1,112 trillion miles, accounting for $83 \%$ of the total number of vehicle-miles traveled (VMT) in the transportation sector (Millar et al. 1982, Oak Ridge 1981). On the average, each auto traveled 10,600 miles. Automobiles carried passengers a total of 2,113 trillion miles, accounting for $74 \%$ of the domestic passenger-miles traveled (PMT), and consumed $75 \%$ of the energy used in domestic passenger travel. The load factor for local travel was 1.87 and for intercity travel was 1.96 .

These figures can be translated to engine load-miles to provide a measure of the work being performed by the engine. In 1980 the curb weight of the average automobile was 3363 lb (Abarcar, Hane and Johnson 1984). If a typical load factor was 1.9 for passengers (averaging $150 \mathrm{lb}$ ) and a typical cargo weight was $501 \mathrm{~b}$, the average gross weight totals to $3698 \mathrm{lb}$. This weight multiplied by the approximately 1,112 trillion miles traveled by automobiles yields a value of 2.06 trillion ton-miles, or 19,700 ton-miles per vehicle. 


\subsubsection{Service Activity Level, 2000}

An average of the forecasts mentioned earlier indicates that the number of vehicle-miles traveled in 2000 will increase to 1.69 trillion miles. The average annual VMT is forecasted to increase slightly, to 12,100 miles. In Scenario $A$, approximately $80 \%$ of the automobiles are gasoline-powered and in Case B, 69\% of the automobiles use gasoline. Unfortunately, the OTA assumptions regarding changes in the average weight of the vehicles in both scenarios were not presented. However, a minimal average weight reduction of 500 ib seems reasonable and will be used for the Scenario A approximation. Assuming that much of the improvement in gasoline fuel economy for Scenario $B$ will also be attributable to weight reduction, the average weight will be further reduced to $2360 \mathrm{lb}$. Assuming the passenger and cargo loads remain relatively unchanged, the engine load-miles can be approximated as 1.91 trillion ton-miles $(17,300$ ton-miles per vehicle) for Scenario $A$ and 1.37 trillion ton-miles $(14,300$ tonmi les per vehicle) for Scenario $B$. 



\subsection{LIGHT TRUCKS}

The entire trucking sector consumes $22.5 \%$ of the gasoline used in transportation. Light trucks are those with a gross vehicle weight (GVW) of less than 10,000 1b. Medium trucks range from 10,001 lb to 19,500 ib GVW; 1ightheavy trucks range from 19,501 1b to 26,000 lb GVW; and heavy-heavy trucks are those over $26,001 \mathrm{1b}$ GWW. In some instances, the categories of trucks are further disaggregated into eight weight classes, with light trucks occupying weight classes 1 and 2 . These weight classes and their weight ranges are shown in Table 3.1 .

TABLE 3.1. Truck Categories by Vehicle Weight (JFA 1976)

\begin{tabular}{|c|c|c|}
\hline Size Class & Number & $\begin{array}{l}\text { Weight Class } \\
\text { Gross Vehicle } \\
\text { Weight (lb) }\end{array}$ \\
\hline \multirow[t]{2}{*}{ Light } & 1 & 6,000 \\
\hline & 2 & $6,000-10,000$ \\
\hline \multirow[t]{3}{*}{ Medium } & 3 & $10,000-14,000$ \\
\hline & 4 & $14,000-16,000$ \\
\hline & 5 & $16,000-19,500$ \\
\hline Light-Hea vy & 6 & $19,500-26,000$ \\
\hline \multirow[t]{2}{*}{ Heavy-Heavy } & 7 & $26,000-33,000$ \\
\hline & 8 & over 33,000 \\
\hline
\end{tabular}

As the size of the trucks increases, there is a marked shift from 0tto cycle, gasoline-powered engines to diesel cycle engines. Thus, while the medium and heavy trucks consumed $80 \%$ as much energy as the light trucks, most of this energy was in the form of diesel fuel. A large proportion of light trucks is also used for recreational purposes; larger vehicles are not commonly used for recreation. Light trucks, therefore, possess energy and end-use characteristics that are notably different from the larger categories. It has been common practice in previous studies to group light trucks together with automobiles because of the similarity in engine size and loads. 
However, data from the Jack Faucett Associates study (1976), the 0ak Ridge transportation data base (1981), and the Argonne data base (Millar et ai. 1982) have presented separate information on automobiles and light trucks. Because of the differences between light trucks and heavier trucks and the convenient availability of disaggregated information, light trucks will be discussed separately.

Light trucks account for $85 \%$ of the vehicles in the trucking sector and consume $87 \%$ of the gasoline. The Otto cycle engines used in these trucks burn both gasoline and liquefied petroleum gas (LPG). However, LPG fuel is used in only $0.34 \%$ as many vehicles as gasoline.

The most comprehensive study in this area appears to be that performed by JFA, Trucking Activity and Fuel Consumption 1973, 1980, 1985, and 1990 (1976). The primary limitations of this study are that it was done eight years ago and that it reviews civilian consumption only. However, data for 1980 and projections can be compared with the Oak Ridge transportation data book and the Argonne data book, which are less thorough but are much more up-to-date. These three studies form the primary references for the information presented in this chapter on light trucks and in the following chapter on medium and heavy trucks. Other sources of information inciude the Federal Highway Administration statistics on all trucks and the Project Independence report, which combined personal trucks with personal automobiles.

\subsection{EFFICIENCY ESTIMATE}

The therinodynamic characteristics of light truck gasoline engines are essentialiy the same as automobile engines, hence, their delivered, or brake, thermal efficiency is approximately the same. For a discussion of these characteristics see Section 2.1. However, because of the larger sizes and weights typical of light trucks, their fuel economy is worse.

Argonne (Millar et al. 1982) has compiled estimated values of average fuel economy in light trucks from a number of sources. These are presented in Table 3.2. The average of these estimates for fuel economy in 1980 is 12.4 mpg. 
IABLE 3.2. Comparison of Fuel Economy Estimates for Light Trucks in 1980 (Millar et a1. 1982)

\begin{tabular}{lcc}
\multicolumn{1}{c}{ Source of Estimate } & & (mpg) \\
\hline Oak Ridge National Laboratory & 13.8 \\
Argonne National Laboratory & 12.7 \\
Office of Policy Planning and Analysis & 12.1 \\
Transportation Systems Center & 14.1 \\
Energy and Environmental Analysis, Inc. & 10.6 \\
Data Resources, Inc. & 10.9
\end{tabular}

\subsection{CAPITAL STOCK INFORMATION}

\subsubsection{Capital Stock Information, 1980}

The number of light trucks in use in 1980 has been estimated by several sources and is shown in Table 3.3. These values are for all light trucks, both civilian and government, unless otherwise noted. Oak Ridge notes in their estimates that $99.6 \%$ of light civilian trucks in operation are powered by gasoline. $L P G$ is used in a little more than $0.3 \%$ and diesel fuel in the remainder.

TABLE 3.3. Comparison of Stock Projections for Light Trucks (Millar et al. 1982, Knorr and Millar 1979, Oak Ridge 1981)

\begin{tabular}{|c|c|c|c|}
\hline Source of Projection & $\frac{\text { Stock }}{1980}$ & $\frac{\left.10^{6}\right)}{2000}$ & $\begin{array}{l}\text { Avg. Annual } \\
\% \text { Change }\end{array}$ \\
\hline Oak Ridge National Laboratory $(a)$ & 30.12 & -- & \\
\hline Argonne National Laboratory & 28.7 & 41.7 & 1.9 \\
\hline Office of Policy Planning and Analysis & 28 & 47 & 2.6 \\
\hline Energy and Environmental Analysis, Inc. & 29.1 & 49.7 & 2.7 \\
\hline Data Resources, Inc. & 30.1 & 42.3 & 1.7 \\
\hline Lidsey-Kaufman & 29 & 42 & 1.8 \\
\hline
\end{tabular}

(a) Civilian consumption only. 
For this study, we will use a capital stock of 29 million light trucks, 87,000 of which are powered by LPG. The total number of diesel light trucks was less than $0.1 \%$.

JFA (1976) estimated that in 1973 there were 980,000 government trucks, most of which were light trucks. If the government truck stock increased at the same rate as the civilian truck stock, there would be approximately $1,560,000$ government trucks in use in 1980. However, because the popularity of light trucks for personal recreation was the primary reason for the growth in the nongovernment sector, it is not likely that federal growth kept pace with private growth. The size of the government truck fleet is thus likely to be somewhere between 980,000 and 1,560,000 vehicles. A mean value of $1,270,000$ vehicles may be a reasonable estimate.

Oak Ridge has estimated that 2,245,000 new light trucks were sold in 1980 . Assuming that $5 \%$ of these sales were diesel engine vehicles, 2,133,000 new otto cycle light trucks were purchased in 1980.

The survival curve for light trucks is slightly more extended than that for automobiles. As seen in Figure 2.7, approximately half of the trucks are still in use after 15 years. By comparison, the "half-life" for automobiles is 10 years.

\subsubsection{Capital Stock Information, 2000}

Because of the similarity in energy and end-use between light trucks and automobiles, several projections of the change in light truck stock to the year 2000 have been made. Table 3.3 shows the results of several models, with stock projections ranging from 42 million to 49.7 million vehicles.

Using a stock of 29 million vehicles in 1980 and an average $2 \%$ growth rate, the projected light-duty vehicle stock in 2000 is 43 million. Assuming that diesel engines are used in $20 \%$ of the trucks in operation by 2000 , the otto cycle light truck stock is $34.4 \mathrm{million}$ vehicles. Further assuming that the number of LPG vehicles remains proportionate, 33.3 million vehicles would be powered by gasoline and 108,000 by LPG. 


\subsection{FUEL CONSUMPTION DEMAND}

\subsubsection{Fuel Consumption Demand, 1980}

Estimates of energy consumption in 1980 and the year 2000 have also been compiled by Argonne and 0ak Ridge. These estimates are shown in Table 3.4, along with estimates from the DOT Transportation Systems Center, and another study at Oak Ridge, Energy Savings Impacts of DOE's Conservation and Solar Programs, (Greene et al. 1981).

TABLE 3.4. Comparison of Energy-Use Projections for Light Trucks (Millar et al. 1982, Knorr and Millar 1979, Oak Ridge 1981)

\begin{tabular}{|c|c|c|c|}
\hline Source of Projection & $\begin{array}{l}\text { Use } \\
1980 \\
\end{array}$ & $\frac{\mathrm{ds})}{2000}$ & $\begin{array}{c}\text { Avg. Annua? } \\
\% \text { Change }\end{array}$ \\
\hline Oak Ridge National Laboratory $(a)$ & 2.6 & -- & \\
\hline Argonne National Laboratory & 2.71 & 2.63 & $(-0.2)$ \\
\hline Office of Policy Planning and Analysis & 2.5 & 3.1 & 1.1 \\
\hline Energy and Environmental Analysis, Inc. & 3.34 & 3.19 & $(-0.2)$ \\
\hline Transportation Systems Center & 2.43 & 1.73 & $(-1.73)$ \\
\hline $\begin{array}{l}\text { Oak Ridge National Laboratory } \\
\text { (Samuels 1981) }\end{array}$ & 2.7 & 4.1 & $(2.3)$ \\
\hline
\end{tabular}

(a) Civilian light trucks only.

When the $128 \times 10^{12}$ Btu of gasoline consumed by government light trucks is added to the Oak Ridge estimate of 2.6 quads in 1980, the Argonne and Dak Ridge values become nearly identical. This study will use this value of 2.71 quads in 1980. In addition to this gasoline, approximately $7.25 \times 10^{12}$ Btu of LPG was used in light trucks.

JFA projected that between 1973 and 1980 the total amount of gasoline consumed would increase from 21,900 million gallons to 29,500 million gallons, at an annual growth of $4.4 \%$. Oak Ridge and Argonne data for 1980 show that gasoline consumption was only 21,700 million gallons, which would be equivalent to 
a $0.1 \%$ annual decrease. The $23 \%$ shortfall is likely to be at least in part due to the dramatic increase in gasoline prices between 1973 and 1980 . It also points to the difficulty in making accurate projections.

\subsubsection{Fuel Consumption Demand, 2000}

Table 3.4 also shows estimates of energy consumption by light trucks in 2000. The projections can be seen to vary widely between a low of 1.73 quads predicted by the Transportation Systems Center and a high of 4.1 quads predicted by Oak Ridge (Greene et a1. 1981). The average annual growth rates are seen to range from $2.3 \%$ to $-1.73 \%$.

This study will assume that a small growth of $0.2 \%$ annually will occur, that diesels will account for $20 \%$ of the energy use, and that the use of LPG remains proportionate. Using these assumptions, the projected consumption of gasoline by 1 ight trucks in 2000 will be 2.82 quads, and $7.55 \times 10^{12}$ Btu will be consumed in the form of LPG.

\subsection{SERVICE ACTIVITY LEVEL}

\subsubsection{Service Activity Level, 1980}

The Oak Ridge (1981) study estimates that the primary use of light trucks in 1980 was for personal transportation. In 1977, this was the primary use for 55\% of the light trucks in operation. Excluding government trucks, the major uses and their distribution among light trucks were as follows:

$\begin{array}{lr}\text { Agriculture } & 12.7 \% \\ \text { Construction } & 8.5 \% \\ \text { Manufacturing } & 1.3 \% \\ \text { Wholesale trade } & 3.9 \% \\ \text { Retail trade } & 5.1 \% \\ \text { For hire } & 0.7 \% \\ \text { Utilities } & 2.3 \% \\ \text { Services } & 7.9 \% \\ \text { Personal transportation } & 55.2 \% \\ \text { Other } & 2.2 \% \\ \text { Total } & 100.0 \%\end{array}$


This distribution is in general agreement with similar information published by Argonne for the use of light trucks in 1975. Argonne further projected changes in use out to the year 2000 and their results will be discussed below.

Estimates and projections of light truck use for 1980 and 2000 have been assembled by Argonne, Oak Ridge, and JFA. These figures for 1980 range from a low of 8,700 vehicle-miles traveled (VMT) to 11,900 VMT. For this study we will use Argonne's value of 9,600 VMT, which is in the middle of the various estimates.

JFA has estimated an average vehicle load and vehicle weight for light trucks. Combining this load (0.28 tons) and weight (2.88 tons) with the stock and VMT information yields a total service of $877 \times 10^{9}$ ton-miles for gasoline vehicles and $2.5 \times 10^{9}$ ton-miles for $L P G$ vehicles.

\subsubsection{Service Activity Level, 2000}

Table 3.5 shows projections from an Argonne model for the change in the use of light trucks between 1975 and 2000 for various services.

TABLE 3.5. Projected Changes in the Use of Light Trucks (Knorr and Millar 1979)

\begin{tabular}{|c|c|c|c|}
\hline Use Sector & $\begin{array}{r}\text { Pro } \\
\text { Light } \\
10^{6} \\
1975 \\
\end{array}$ & $\begin{array}{l}\text { jected } \\
\text { Trucks } \\
\frac{\text { Trucks }}{2000}\end{array}$ & $\begin{array}{l}\text { Percent } \\
\text { Change }\end{array}$ \\
\hline Personal & 11.3 & 27.0 & 139 \\
\hline Service/Utility & 2.1 & 7.3 & 248 \\
\hline Agriculture & 3.0 & 4.0 & 33 \\
\hline Manufacturing & 0.3 & 0.8 & 167 \\
\hline Government & 1.0 & 1.5 & 56 \\
\hline Wholesale/Retail & 0.9 & 1.9 & 11 \\
\hline Other & 1.4 & 1.8 & 29 \\
\hline Total & 20.0 & 44.3 & 117 \\
\hline
\end{tabular}


Information describing the manner in which these changes in light truck use (such as the number of ton-miles) will affect service measures was not provided by the model results. However, estimates of the change in VMT to 2000 are available. Average annual growth estimates range from $0.1 \%$ to $0.9 \%$. Argonne estimated an average growth of $0.3 \%$ annually, and because it is in the middle range of the projections, it will be used here. The average annual VMT in 2000 is therefore expected to increase to 10,100 miles. Assuming that the average vehicle weight and load remain constant, the projected service in 2000 is $1,063 \times 10^{9}$ ton-miles for gasoline vehicles and $3.62 \times 10^{9}$ ton-miles for light trucks fueled by LPG. 


\subsection{MEDIUM AND HEAVY TRUCKS}

Trucks that are heavier than 10,000 1b GVM are classified as inedium, light-heavy, or heavy-heavy trucks. Recall from Table 3.1 that these trucks compose the larger six weight classes of the eight that are used to categorize trucks. Though medium, light-heavy, and heavy-heavy trucks compose only $15 \%$ of the total number of vehicles in the trucking sector, they consumed nearly $45 \%$ of the energy. This energy was supplied as either diesel fuel, gasoline, or LPG.

As the size of the trucks increases, so does the tendency to use a diesel cycle engine rather than an otto cycle engine. This shift occurs because the unthrottled diesel engine has a higher efficiency, because diesel fuel has approximately $10 \%$ more energy per volume than gasoline, and because the heavier weight of the diesel engine is not as great a penalty with larger trucks as it is with lighter vehicles. As a consequence of this preference for diesel engines, $80 \%$ of the energy used by medium and heavy trucks is in the form of diesel fuel, $19 \%$ is gasoline, and less than $1 \%$ is LPG. The primary sources of information regarding medium and heavy trucks are the same as those for light trucks: JFA (1976), Oak Ridge (1981) and Argonne (Millar et a1. 1982) (see Chapter 3).

\subsection{EFFICIENCY ESTIMATES}

The thermodynamic characteristics of truck 0tto cycle engines are essentially the same as automobile engines; hence, their delivered, or brake thermal efficiency is approximately the same. For a discussion of these characteristics see Section 2.1. It is important to remember that the fuel economy of the vehicie can be strongly influenced by changes other than those related to the engine. For example, wind deflectors placed on top of the cab and in front of the trailer can reduce fuel consumption by $5 \%$.

Jack Faucett (JFA), A. D. Little (ADL), and the American Transportation Association (ATA) estimated the average fuel economy in 1975 for each of the eight truck weight classes. These estimates for medium and heavy trucks are 
shown in Table 4.1. The variation in fuel economy as a function of the gross vehicle weight is shown in Figure 4.1 .

TABLE 4.1. Comparison of Truck Fuel Economy by Gross Vehicle Weight (JFA 1976)

\begin{tabular}{|c|c|c|c|}
\hline $\begin{array}{l}\text { Gross Vehicle } \\
\text { Weight Class }\end{array}$ & $\frac{\text { Local }}{\mathrm{ADL}}$ & $\frac{\text { Gasoline }}{\text { ATA }}$ & $\frac{(\operatorname{mpg})}{\text { JFA }}$ \\
\hline 3 & 8.31 & & 8.96 \\
\hline 4 & 6.8 & 7.08 & 7.86 \\
\hline 5 & 5.8 & & 6.86 \\
\hline 6 & 5.7 & 5.81 & 5.53 \\
\hline 7 & 5.31 & & 4.09 \\
\hline & & 5.32 & \\
\hline 8 & 4.9 & & 3.76 \\
\hline
\end{tabular}

\subsection{CAPITAL STOCK INFORMATION}

\subsubsection{Capital Stock Information, 1980}

Several organizations have estimated the medium and heavy-duty truck stock in 1980. These estimates include both 0tto and diesel engine trucks and are summarized in Table 4.2. The aggregated and the disaggregated stock information provided by 0ak Ridge and Argonne are generally very close; however, since more detajled information and projections are available from Argonne, their numbers will be used in this report. The Argonne estimates and projections of 0tto cycle truck stock are shown in Table 4.3. Gasoline is used in $99.7 \%$ of these engines, with LPG used in the remainder.

Oak Ridge has estimated the sales of domestic and imported trucks for 1980. These sales figures are shown in Table 4.4 .

Information describing the percent of sales that were 0tto cycle versus diesel cycle engines was not given in the 0ak Ridge study. To estimate these values, data from the Argonne study were used. An estimate for Otto cycle 


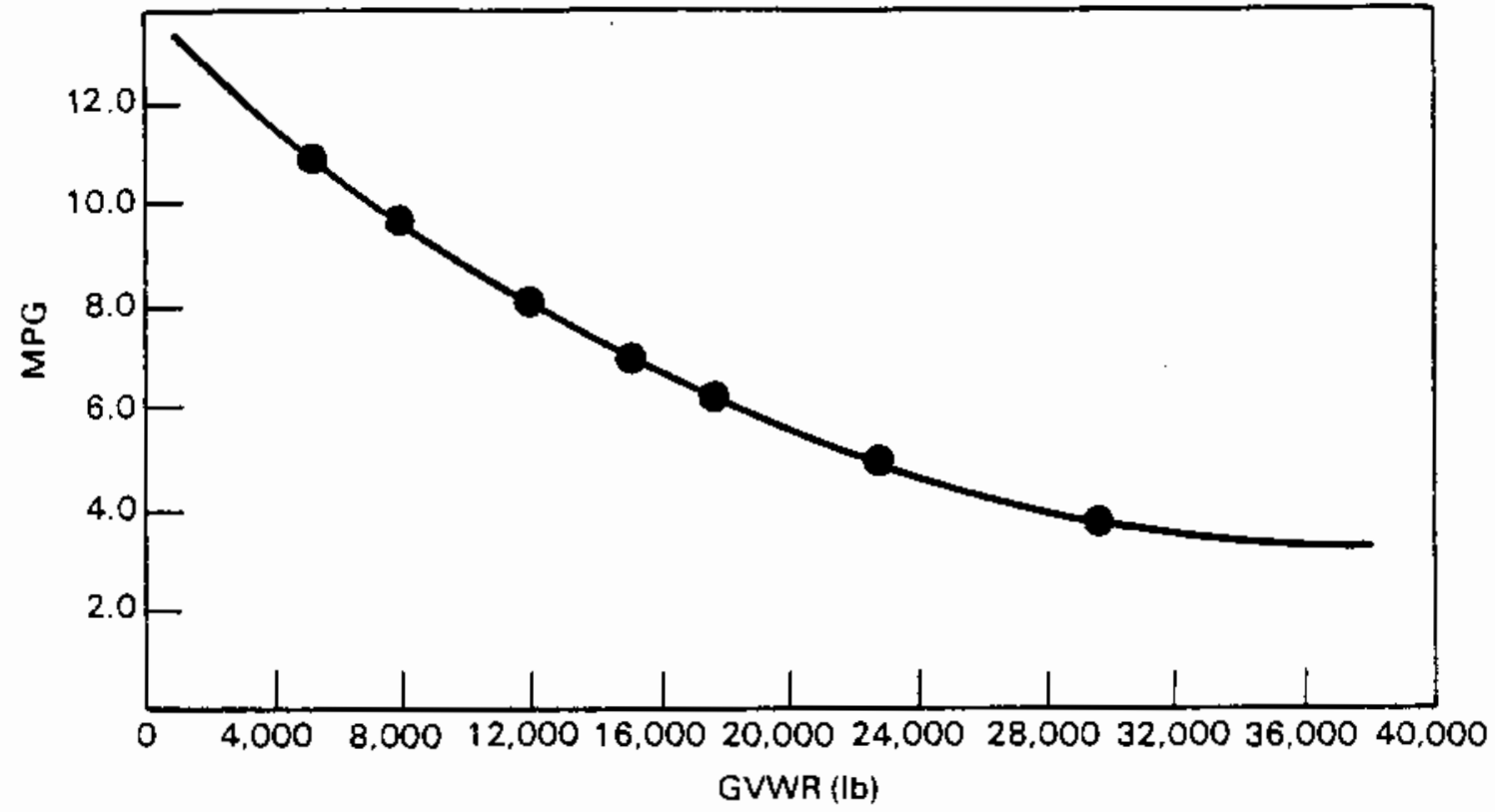

FIGURE 4.1. Fuel Consumption Rates for Local Gasoline-Powered Vehicles by Gross Vehicle Weight Ratịng (JFA 1976)

TABLE 4.2. Comparison of Stock Projections for All Medium and Heavy Trucks (Millar et al. 1982)

\begin{tabular}{lcccc}
\multicolumn{1}{c}{ Source of Projection } & $\frac{\text { Stock }}{1980}$ & $\frac{2000}{100}$ & & $\begin{array}{c}\text { Avg. Annual } \\
\% \text { Change }\end{array}$ \\
\cline { 1 - 2 } Oak Ridge National Laboratory & & 5.15 & & \\
Argonne National Laboratory & 5.31 & 8.61 & 2.4 \\
Oak Ridge National Laboratory (a) & 7.16 & 12.68 & 2.9 \\
Office of Policy Planning and Analysis & 4.5 & 5.2 & 0.8 \\
Energy and Environmental Analysis, Inc. & 4.45 & 4.97 & 0.6 \\
Oata Resources, Inc. & 4.7 & 5.5 & 0.5
\end{tabular}

(a) Oak Ridge estimate (Greene et al. 1981). 
TABLE 4.3. Estimated and Projected Otto Engine Truck Stock by Size Category (Millar et al. 1982)

\begin{tabular}{|c|c|c|c|}
\hline $\begin{array}{c}\text { Size } \\
\text { Category } \\
\end{array}$ & $\frac{\text { Stock }}{1980}$ & $\frac{\text { s sands) }}{2000}$ & $\begin{array}{l}\text { Avg. Annual } \\
\% \text { Change }\end{array}$ \\
\hline Medi um & 2,085 & 2,166 & $0.2 \%$ \\
\hline Light-heavy & 1,255 & 1,129 & $-0.5 \%$ \\
\hline Heavy-heavy & 246 & 7.6 & $-16 \%$ \\
\hline Total & 3,586 & 3,303 & $-0.4 \%$ \\
\hline
\end{tabular}

TABLE 4.4. Domestic and Imported Truck Sales in $1980^{(a)}$ (Oak Ridge 1981)

$\begin{array}{lcc}\frac{\text { Trucks }}{\text { Medium }} & \frac{\text { Domestic Sales }}{6,000} & \frac{\text { Imported Sales }(a)}{--} \\ \text { Light-heavy } & 89,000 & 5,000 \\ \text { Heavy-heavy } & 175,000 & \end{array}$

(a) Includes captive imports.

truck sales can be made by assuming that the change in gasoline truck stock is reflected by the sales and by assuming a $4 \%$ retirement rate. The estimated sales are shown in Table 4.5. The preference for diesel engines in heavy-heavy trucks is assumed to be near $100 \%$, therefore 0tto engine sales in this category were estimated to be minimal.

TABLE 4.5. Estimated Otto Cycle Truck Sales in 1980

\begin{tabular}{lr} 
Trucks & \multicolumn{1}{c}{ Sales } \\
Medium & 5,850 \\
Light-heavy & 82,600 \\
Heavy-heavy & 53,000
\end{tabular}




\subsubsection{Capital Stock Information, 2000}

The projected changes in total truck stock by 2000 are also shown in Table 4.2. The overall average annual growth rate estimates range from $0.5 \%$ to $2.9 \%$ with resultant stock estimates ranging from $4,970,000$ to $12,680,000$ trucks. The Argonne values will be used here because their projections are in the middle of the range and because the most detailed information is available from this source. Estimates of the Otto cycle truck stock by size category have been provided in Table 4.3. These data agree well with an in-house evaluation that applied JFA projections to 0ak Ridge stock information. As the tabie indicates, Argonne predicts that trucks in the heavy-heavy category will be almost entirely diesel-powered in 2000.

\subsection{FUEL CONSUMPTION DEMAND}

\subsubsection{Fuel Consumption Demand, 1980}

The energy used by medium- and heavy-duty trucks has been estimated by several organizations and is summarized in Table 4.6. Argonne and 0ak Ridge provide nearly identical estimates of total energy use, though their estimates of gasoline consumption vary by a factor of two. Oak Ridge (1981) estimates that approximately $400 \times 10^{12}$ Btu of gasoline and $4.0 \times 10^{12}$ Btu of LPG were

IABLE 4.6. Comparison of Energy-Use Projections for Medium and Heavy Trucks (Mililar et al. 1982)

\begin{tabular}{|c|c|c|c|}
\hline Source of Projection & \multicolumn{2}{|c|}{$\begin{array}{c}\text { Energy Use } \\
\text { (quads) }\end{array}$} & $\begin{array}{l}\text { Avg. Annual } \\
\% \text { Change }\end{array}$ \\
\hline Oak Ridge National Laboratory & 2.01 & & \\
\hline Argonne National Laboratory & 2.01 & 3.15 & 2.3 \\
\hline Oak Ridge National Laboratory (a) & 3.3 & 4.8 & 1.9 \\
\hline Office of Policy Planning and Analysis & 2.3 & 3.0 & 1.3 \\
\hline Energy and Environmental Analysis, Inc. & 2.33 & 2.95 & 1.2 \\
\hline Transportation Systems Center & 2.31 & 2.98 & 1.3 \\
\hline
\end{tabular}

(a) Oak Ridge estimate (Greene et al. 1981). 
consumed in this category; Argonne (Millar et al. 1982) estimates that $900 \times$ $10^{12}$ Btu of gasoline was consumed. The reason for this difference is not clear, since the vehicle stock estimates are similar. This study will use a mean value of $650 \times 10^{12}$ Btu for gasoline consumption and $4.0 \times 10^{12}$ Btu for LPG.

Gasoline consumption data by truck size categories were not directly available. A combination of Argonne, Oak Ridge, and JFA information yields the estimates shown in Table 4.7 .

TABLE 4.7. Otto Engine Truck Energy Consumption in 1980

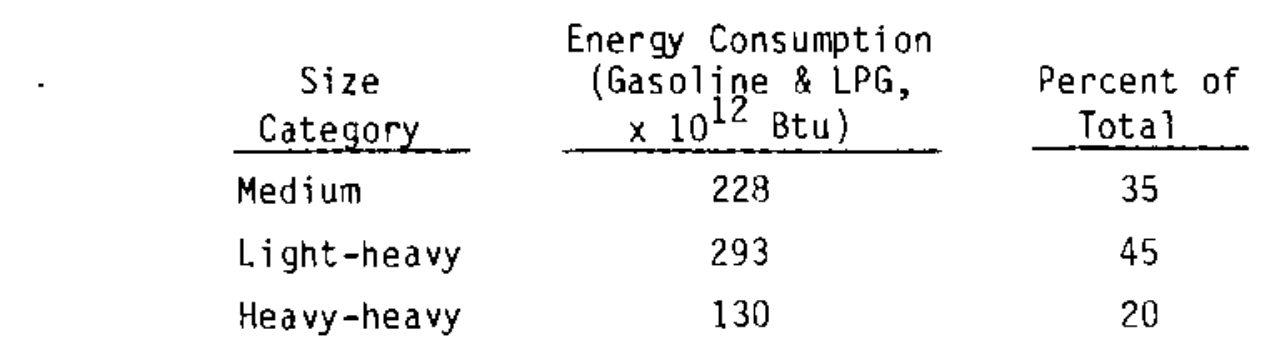

\subsubsection{Fuel Consumption Demand, 2000}

Projections of total energy use in the year 2000 are also given in Table 4.6. Unfortunately, direct estimates of gasoline consumption were not provided. If we use the Argonne stock data and assume that changes in gasoline consumption roughly parallel changes in 0tto engine stock, then approximately $600 \times 10^{12}$ Btu of gasoline will be consumed in 2000 . This estimate agrees with a similar analysis of JFA projections. Again, assuming that otto engine fuel economy is largely unchanged, the projections show $590 \times 10^{12}$ Btu of gasoline and $4.4 \times 10^{12}$ Btu of LPG used. This study will estimate consumption at $600 x$ $10^{12}$ Btu of gasoline and $4.4 \times 10^{12}$ Btu of LPG.

If the change in energy use in the size categories parallels the change in truck stock, then the energy use in each category would be as shown in Table 4.8 . 
TABLE 4.8. Projected 0tto Engine Truck Energy Consumption in 2000

\begin{tabular}{|c|c|}
\hline $\begin{array}{l}\text { Energy Consumption } \\
\text { (Gasol ine \& LPG, } \\
\times 10^{12} \text { Btu) }\end{array}$ & $\begin{array}{l}\text { Percent of } \\
\text { Total }\end{array}$ \\
\hline 237 & 47 \\
\hline 265 & 52 \\
\hline 4.0 & 1 \\
\hline
\end{tabular}

\subsection{SERVICE ACTIVITY LEVEL}

\subsubsection{Service Activity Leve], 1980}

JFA has estimated several characteristics of otto cycle truck activity for 1980 for each of the eight weight classes. They have analyzed the activity of trucks by the type of fuel, type of travel (intercity or local) and by weight class. Their results show that on the average gasoline-fueled trucks travel less than their diesel counterparts. Estimates regarding the average annual miles per vehicle, total vehicle-miles, average vehicle load, and total tonmiles are included.

Combining JFA's activity estimates with the stock information developed earlier yields the activity characteristics shown in Table 4.9.

Oak Ridge has compiled information on the major uses of inedium and heavy trucks. The categories of end use reviewed include agriculture, construction, manufacturing, wholesale trade, retail trade, for hire, utilities, services, personal transportation, and others. The distribution of truck use alnong these categories in 1977 is shown in Table 4.10 .

\subsubsection{Service Activity Level, 2000}

Projected changes to 2000 in the overall number of vehicle-miles traveled have been summarized by Argonne (Millar et a1. 1982). These estimates of average annual growth range from $-0.5 \%$ to $2.7 \%$. Because of the anticipated growth of diesel engine use, much of this growth is likely to occur with diesel-fueled trucks. However, specific descriptions of the projected growth in gasoline versus diesel trucks were not given. Assuming that the average service of 
TABLE 4.9. Activity for Gasoline-Fueled Trucks in 1980

\begin{tabular}{|c|c|c|c|}
\hline \multirow[b]{2}{*}{ Average Vehicle Miles } & \multicolumn{3}{|c|}{ Truck Size Class } \\
\hline & Medium & Light-heavy & Heavy-heavy \\
\hline $\begin{array}{l}\text { Stock of Vehicles } \\
\text { (thousands) }\end{array}$ & 2,085 & 1,255 & 246 \\
\hline $\begin{array}{l}\text { Average Annual Miles } \\
\text { per Vehicle }\end{array}$ & 11,740 & 10,170 & 15,590 \\
\hline $\begin{array}{l}\text { Total Vehicle Miles } \\
\text { (millions) }\end{array}$ & 24,480 & 12,770 & 3,840 \\
\hline $\begin{array}{l}\text { Average Vehicle } \\
\text { Load (tons) }\end{array}$ & 0.96 & 1.58 & 3.61 \\
\hline $\begin{array}{l}\text { Average Total Weight } \\
\text { (tons) }\end{array}$ & 3.82 & 6.26 & 12.6 \\
\hline $\begin{array}{l}\text { Total Ton-Miles } \\
\text { (millions) }\end{array}$ & 93,500 & 79,900 & 48,400 \\
\hline
\end{tabular}

gasoline trucks remains unchanged, and that changes in activity are primarily a function of changes in stock, the projected activity in 2000 is as shown in Table 4.11 . 
TABLE 4.10. Percentage Distribution of Truck Energy Consumption by Major Use and Size Class, $1977^{(a)}$ (Oak Ridge 1981)

\begin{tabular}{|c|c|c|c|c|c|}
\hline \multirow[b]{2}{*}{ Major Use } & \multicolumn{4}{|c|}{ Size Class(b) } & \multirow[b]{2}{*}{ Total } \\
\hline & \multirow[t]{2}{*}{ Light } & \multirow[t]{2}{*}{ Medium } & $\begin{array}{l}\text { Light- } \\
\text { heavy }\end{array}$ & $\begin{array}{l}\text { Heavy-(C) } \\
\text { heavy } \\
\end{array}$ & \\
\hline & & & \multicolumn{2}{|c|}{ Column percents } & \\
\hline Agriculture & 12.7 & 14.5 & 13.6 & 6.6 & 10.8 \\
\hline Construction & 8.5 & 8.9 & 11.1 & 10.0 & 9.2 \\
\hline Manufacturing & 1.3 & 4.6 & 5.2 & 10.6 & 4.8 \\
\hline Wholesale trade & 3.9 & 20.7 & 24.8 & 13.6 & 9.1 \\
\hline Retail trade & 5.1 & 12.5 & 14.3 & 5.8 & 6.1 \\
\hline For hire & 0.7 & 8.9 & 11.1 . & 41.9 & 15.6 \\
\hline Utilities & 2.3 & 4.1 & 4.2 & 0.7 & 2.0 \\
\hline Services & 7.9 & 11.8 & 7.1 & 2.2 & 6.2 \\
\hline $\begin{array}{l}\text { Personal trans- } \\
\text { portation }\end{array}$ & 55.2 & 5.6 & 0.1 & (d) & 31.3 \\
\hline other & 2.2 & 8.4 & 8.6 & 8.7 & 5.1 \\
\hline \multirow[t]{2}{*}{ Total } & 100.0 & 100.0 & 100.0 & 100.0 & 100.0 \\
\hline & \multicolumn{5}{|c|}{ Row percents } \\
\hline Agriculture & 66.2 & 8.1 & 5.1 & 20.6 & 100.0 \\
\hline Construction & 52.2 & 5.8 & 4.9 & 37.0 & 100.0 \\
\hline Manufacturing & 15.1 & 5.8 & 4.4 & 74.7 & 100.0 \\
\hline Wholesale trade & 24.2 & 13.7 & 11.1 & 50.9 & 100.0 \\
\hline Retail trade & 46.6 & 12.2 & 9.5 & 31.7 & 100.0 \\
\hline For hire & 2.6 & 3.4 & 2.9 & 91.1 & 100.0 \\
\hline Utilities & 67.0 & 12.4 & 8.8 & 11.7 & 100.0 \\
\hline Services & 71.9 & 11.4 & 4.6 & 12.0 & 100.0 \\
\hline $\begin{array}{l}\text { Personal trans- } \\
\text { portation }\end{array}$ & 98.9 & 1.1 & (d) & (d) & 100.0 \\
\hline Other & 24.8 & 9.9 & 6.9 & 58.3 & 100.0 \\
\hline $\begin{array}{l}\text { Percent of Total } \\
\text { Energy Consumption }\end{array}$ & 56.1 & 6.0 & 4.1 & 33.9 & 100.0 \\
\hline
\end{tabular}

(a) Government trucks not included.

(b) These size classes are based on the actual average gross vehicle weight ratings of trucks during the year prior to the survey and do not necessarily correspond to the manufacturers' suggested gross vehicle weight rating.

Truck size classes: Light - Classes 1 and 2 (0-10,000 1b GVW);

Medium - Classes 3 through $5(10,001-19,500$ 1b GVW) ;

Light-heavy - Class $6(19,501-26,000$ lb GVW $)$;

Heavy-heavy - Classes 7 and $8(26,001$ lb GVW or more).

(c) Heavy-heavy trucks appear to have been undercounted, therefore the energy-use estimates may be low.

(d) Negligible. 
TABLE 4.11. Activity for Gasoline- and LPG-Fueled Trucks in 2000

\begin{tabular}{|c|c|c|c|}
\hline \multirow[b]{2}{*}{ Average Vehicle-Miles } & \multicolumn{3}{|c|}{ Truck Size Class } \\
\hline & Medium & Light-heavy & Heavy-heavy \\
\hline $\begin{array}{l}\text { Stock of Vehicles } \\
\text { (thousands) }\end{array}$ & 2,166 & 1,129 & 7.6 \\
\hline $\begin{array}{l}\text { Average Annual Miles } \\
\text { per Vehicle }\end{array}$ & 11,740 & 10,170 & 15,590 \\
\hline $\begin{array}{l}\text { Total Vehicle-Miles } \\
\text { (millions) }\end{array}$ & 25,240 & 11,480 & 119 \\
\hline $\begin{array}{l}\text { Average Vehicle } \\
\text { Load (tons) }\end{array}$ & 0.96 & 1.58 & 3.61 \\
\hline $\begin{array}{l}\text { Average Total Weight } \\
\text { (tons) }\end{array}$ & 3.82 & 6.26 & 12.6 \\
\hline $\begin{array}{l}\text { Total Ton-Miles } \\
\text { (millions) }\end{array}$ & 95,400 & 71,900 & 1,500 \\
\hline
\end{tabular}




\section{REFERENCES}

Abarcar, R. B., G. J. Hane and D. R. Johnson. 1984. Lightweight Materials for Ground Transportation. PNL-5192, Pacific Northwest Laboratory, Richland, Washington.

Bryzik, W. 1978. "Adiabatic Diesel Engine," Industrial Research Development. Vol. 20 , No. 1 .

Bryzik, W. 1980. Adiabatic Engine Program. Proceedings of Automotive Technology Development Contractors Coordination Meeting, Dearborn, Michigan. U.S. Department of Energy, Washington, D.C.

Energy Resources Counci1. 1976. The Report by the Federal Task Force on Motor Vehicle Goals Beyond 1980. Washington, D.C.

Garrett/Ford Advanced Gas Turbine Program Summary. October 1981. Garrett Turbine Engine Co., Phoenix, Arizona, and Ford Motor Company, Dearborn, Michigan.

Glance, P. 1979. TARADCOM Engine Research and Development Overview. Highway Vehicle Systems Contractors Coordination Meeting, Dearborn, Michigan. U.S. Department of Energy, Washington, D.C.

Greene, D. et al. 1981. Energy Savings Impacts of D0E's Conservation and Solar Programs. ORNL/TM-7690-V2, Oak Ridge National Laboratory, Oak Ridge, Tennessee.

Hittman Associates. 1974. A Technology Assessment of the Transition to Advanced Automotive Propulsion Systems. Columbia, Maryland.

Hopp, W. et al. 1981. Overview of Energy Conservation Research Opportunities. PNL 3944, Pacific Northwest Laboratory, Richland, Washington.

Imhoff, C. H., A. Liberman and H. B. Ashton. 1982. U.S. Energy Conversion and Use Characteristics. PNL-4075, Pacific Northwest Laboratory, Richland, Washington.

Jack Faucett Associates, Inc. 1976. Trucking Activity and Fuel Consumption 1973, 1980, 1985, and 1990. JACKFAU-79-231/3, Jack Faucett Associates, Inc., Chevy Chase, Maryland.

Jet Propulsion Laboratory. 1975. Should We Have a New Engine? JPL SP43-17, Pasadena, California.

Katz, R. N. and E. M. Lenoe. 1981. Ceramics for Diesel Engines: Preliminary Results of a Technology Assessment. Automotive Technology Contractors Coordination Meeting, Dearborn, Michigan. U.S. Department of Energy, Washington, D.C. 
Knorr, R. and M. Millar. 1979. Projections to Automobile, Light Truck, and Bus Stocks and Sales, to the Year 2000. ANL/CNSV-TM-22, Argonne National Laboratory, Argonne, Illinois.

Liu, C. T. 1981. Metals for Advanced Heat Engines. Oak Ridge National Laboratory, Oak Ridge, Tennessee.

Loxley, C. J. et al. 1981. Past and Future Irends in Automobile Sales. D0THS-805 669, Wharton EFA, InC., Philadelphia, Pennsylvania.

Millar, M. et a1. 1982. Baseline Projections of Transportation Energy ConSumption by Mode: 1981 Update. ANL/CNSV-28, Argonne National Laboratory, Argonne, Illinois.

0ak Ridge National Laboratory. 1981. Transportation Energy Conservation Data Book: Edition 5, ONRL-5765, Oak Ridge National Laboratory, Oak Ridge, Tennessee.

Rice, R. W. An Assessment of the Use of Ceramics in Heat Engines. Naval Research Laboratory, Washington, D.C.

Samue15, G. 1981. Transportation Energy to the Year 2010. ORNL-5745, 0ak Ridge National Laboratory, Oak Ridge, Tennessee.

U.S. Department of Energy. 1980. Automotive Gas Turbine Development. Office of Transportation Programs, Washington, 0.C.

U.S. Departinent of Transportation. 1980. FAA Aviation Forecasts, Fiscal Years 1981-1982. Washington, D.C.

U.S. Department of Transportation. 1979a. Highway Statistics 1979. Washington, 0.C.

U.S. Department of Transportation. 1979b. Proceedings: Conference on Basic Research Directions for Advanced Automotive Technology. Boston, Massachusetts.

U.S. Office of Technology Assessment (OTA). 1979a. Automobile Transportation System. Washington, 0.C.

U.S. Office of Technology Assessment. 1979b. Technology Assessment of Changes in the Future Use and Characteristics of the Automobile Transportation System, Volume II, Technical Report, Washington, 0.C. 


\section{OISTRIBUTION}

No. of

Copies

\section{OFFSITE}

6 M. E. Gưnn

CE-142

U.S. Department of Energy

1000 Independence Avenue

Washington, DC 20585

6 J. J. Eberhardt

$C E-142$

U.S. Department of Energy

1000 Independence Avenue

Washington, DC 20585

6 T. Levinson

CE-142

U.S. Department of Energy

1000 Independence Avenue

Washington, DC 20585

27 DOE Technical Information Center

6 R. B. Abarcar

Energetics, Inc.

9210 Route 108

Columbia, MD 21045

T. T. Bramlette

Sandia Laboratories

P.0. Box 969

Livermore, CA 94550

J. A. Carpenter, Jr.

Oak Ridge National Laboratory

Bldg. 4508 Room 263

P.0. Box X

Dak Ridge, TN 37831

M. Clayton

Jet Propulsion Laboratory

4800 Dak Grove Drive

Mail Code 125-159

Pasadena, CA 91109
No. of

Copies

M. Dastoor

Jet Propulsion Laboratory

4800 Dak Grove Drive

Mail Code 122-123

Pasadena, CA 91109

T. M. Dyer

Sandia Laboratories

P.0. Box 969

Livermore, CA 94550

C. Fink

Energetics, Inc.

9210 Route 108

Columbia, MO 21045

R. E. Holtz

Argonne National Laboratory 9700 South Cass Avenue

Building 330

Argonne, IL 60439

S. Hsu

National Bureau of Standards

Bldg. 220 Room A-215

Washington, OC 20234

M. Kaminsky

Argonne National Laboratory 9700 South Cass Avenue

Argonne, IL 60439

X. G. Kreider

National Bureau of Standards

Physics B1dg. B-50

Washington, DC 20234

R. Phen

Jet Propulsion Laboratory

4800 0ak Grove Drive

Pasadena, CA 91109 
No. of

Copies

C. H. Robinson

Sandia Laboratories

P.0. Box 969

Livermore, CA 94550

A. Schaffhauser

Oak Ridge National Laboratory

Bldg. 4508 Mailcode 110

P.0. Box $X$

Oak Ridge, TN 37830

K. Smith

A)buquerque Operations Office

P.0. Box 5400

Albuquerque, NM 87185

W. H. Thielbahr

Idaho Operations office

550 Second Street

Idaho Falls, I0 83401

\section{ONSITE}

DOE Richland Operations Office

H. E. Ransom

D. R. Segna

38 Pacific Northwest Laboratory

W. B. Ashton

D. L. Brenchley

A. D. Chockie

J. E. Danko

R. A. Hutchinson

C. H. Imnoff

D. R. Johnson (24)

J. K. Young

Publishing Coordination MA (2)

Technical Information (5) 